\title{
Do Caipira
}

\section{Picando Fumo}

\section{a Chitãozinho}

LUCIA LIPPI OLIVEIRA é pesquisadora do CPDOC-FGV.

\author{
e Xororó,
}

ou da roça ao rodeio

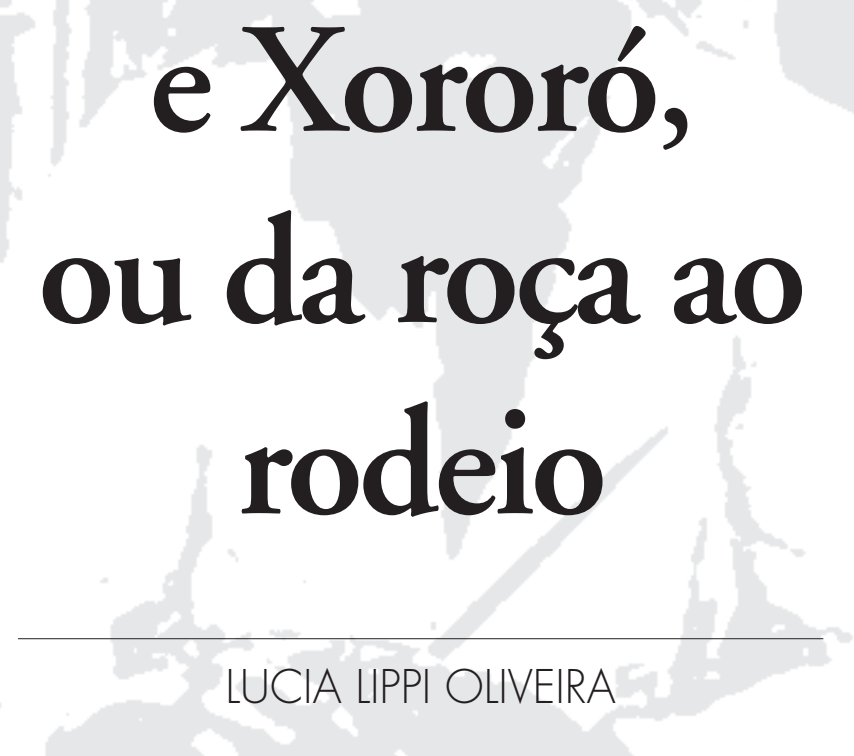

"Decerto aquele Caipira picando fumo, pintado por Almeida Júnior, em 1893, o legítimo Jeca Tatu ridicularizado por Monteiro Lobato nos seus artigos 'Velha praga' e 'Urupês', em 1914, e cantado por Mário de Andrade nos versos de Viola quebrada' em 1929, desapareceu. O progresso chega, engolindo o sertão. No século $X X$, o homem do campo transmutou-se, camaleônico, envolvido pela cultura do forasteiro, seduzido pelas novidades da civilizaçâo, querendo o conforto de alpargatas no lugar dos pés descalços, da roçadeira substituindo a foice” (Nepomuceno, 1999, p. 27). 


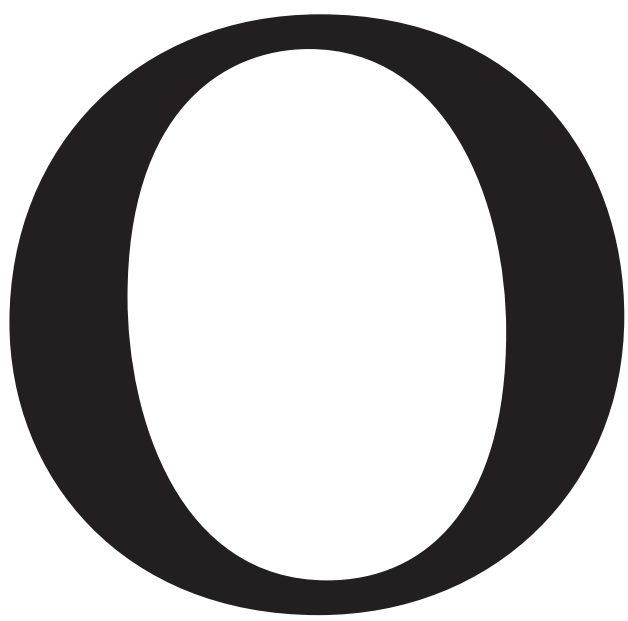

Este texto faz parte da pesquisa "O Brasil dos Imigrantes"
Caipira Picando Fumo, uma das mais conhecidas telas de Almeida Júnior, é considerada por Jorge Coli exemplar do procedimento do pintor. A faca que o caipira usa constituiria o centro do quadro e remeteria a uma violência latente (1). Como nos demais quadros de Almeida Júnior, não existiria nesse nenhuma afetação sentimental ou heróica. Seus quadros fogem da eloqüência, como do pitoresco e do narrativo. Essa aparente simplicidade, que não carrega o caipira de sentimentos, passa uma imagem forte, ainda que isolada socialmente. Trata-se exatamente do isolamento social vivenciado por esse homem na sociedade brasileira. Diz Jorge Coli: "Sem nenhuma concessão a um pitoresco feito de detalhes supérfluos, o picador de fumo, na sua postura concentrada, expondo de modo crucial sua faca, interpondo-a de fato entre si mesmo e o espectador, protege-se, protege sua autonomia individualizada, protege, pela violência possível, o lugar frágil que ocupa no mundo" (Coli, 2002, p. 31) (2).

Se essa é uma análise atual de Almeida Júnior e de seu Caipira Picando Fumo, isso nem sempre foi assim. A simplicidade de sua pintura já fora elogiada por Lobato, principalmente por seu naturalismo, mas a quase pobreza da casa e das vestes do caipira o tornava representante de um mundo simples, singelo, pobre, que deveria ser ultrapassado pela urbanização e pela industrialização em curso no estado de São Paulo.

Iremos acompanhar aqui as diferentes representações do homem rural paulista, apontar como ele foi tratado
Isso também foi notado pelos artistas que, a convite da Pinacoteca do Estado de São Pau lo, criaram obras para compor a exposição "Almeida Júnior Revisitado".

2 Coli associa a estrutura visual do caipira ao mundo social analisado por Maria Sylvia de Carvalho Franco em seu Ho mens Livres na Sociedade Escravocrata. 


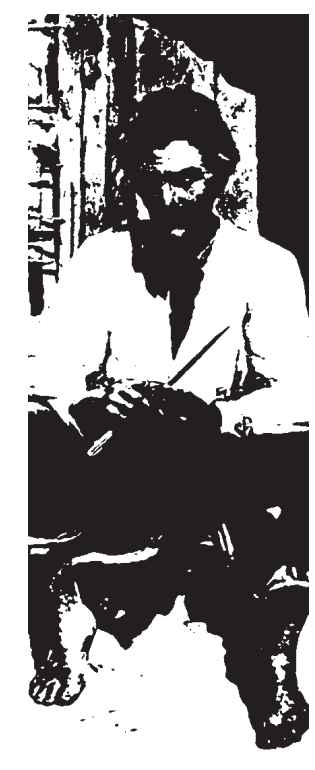

\section{HOMEM RURAL PAULISTA}

A historiografia paulista, desde o fim do século XIX, buscou resgatar a contribuição dos costumes indígenas para a cultura regional, assim como as características da personalidade do homem rústico paulista - o caboclo ou caipira. Fruto da miscigenação entre o branco e o índio, o caboclo é apresentado como o correspondente humilde do bandeirante, como uma versão equivalente ao sertanejo nordestino, e é tratado como reserva da nacionalidade ou alicerce para a formação de uma raça forte (Ferreira, 1999, p. 103).

Esse constructo se fez presente na literatura e também nas artes plásticas. Entre os sócios do Instituto Histórico e Geográfico de São Paulo está Almeida Júnior, artista que, como já observamos, fixou o modelo visual do caipira paulista. Essa representação tem como pano de fundo o choque entre a cidade e o campo. E nela se fala do mundo estável das fazendas e das pequenas cidades do sertão, por oposição ao tumulto e desagregação da emergente metrópole paulista.

No final dos anos 1910 e início dos 1920 , aparece nas páginas da Revista do Brasil um duplo estatuto para o Brasil: país jovem, aberto ao novo, mas, ao mesmo tempo, imaturo edespreparado. E, precisamos lembrar, será com essa ambivalência que será encarada a chegada dos imigrantes europeus. Como brancos, representam a esperança de purificação da raça, mas também significam um perigo diante da imaturidade do povo, que é triste, idealista, passivo, jeca-tatu (Luca, 1999). Essa dicotomia juventudeimaturidade marca os diferentes retratos do Brasil, mesmo aqueles que pretendem uma renovação do pensamento brasileiro. A representação do homem brasileiro (sertanejo, caipira e depois Jeca Tatu) como um homem sem qualidades se contrapõe à exaltação dos atributos da natureza. É daí que se desdobra a necessidade de criar uma narrativa sobre tipos nacionais capaz de tirar do país a marca da incapacidade.

O homem do interior, o trabalhador das áreas rurais, já recebera menção nas obras dos viajantes, dos cronistas que durante o século XIX visitaram o país. De modo geral fora ressaltado o isolamento, a ignorância e a ociosidade em que viviam. Ou seja, as distâncias geográficas e socioculturais entre esse homem e o das cidades do litoral. Havia como que uma oscilação entre uma valorização positiva, que destacava a força, a autenticidade e a comunhão com a natureza, e uma caracterização negativa, cujo traço principal era a preguiça (3).

Será com esse background que será ouvida a fala de Monteiro Lobato denunciando a atividade predatória do caboclo, seu caráter nômade e sua imprevidência (4). Lobato, então fazendeiro que herdara uma grande extensão de terra decadente, apesar dos esforços que faz, não consegue soerguêla. A fazenda vai mal e ele dirige, em 1914, uma carta ao jornal $O$ Estado de S. Paulo em que condena, entre outros males, o hábito antigo do caipira de fazer queimadas. Tratase do texto que ficou conhecido como "Velha Praga". A este segue-se outro, "Urupês", que será também título de livro de contos publicado em 1918 com enorme sucesso.

Para Lobato, o caboclo - chamado de Jeca Tatu - pode ser bonito no romance, mas é feio na realidade. A natureza e suas facilidades tornam-se um obstáculo à regeneração do caboclo, já que ele não tem que enfrentar a hostilidade do ambiente. O Jeca, como um anti-herói, é chamado de "piolho da terra" e "orelha de pau", e sua caracterização se contrapõe aos que idealizam os índios, os caboclos, os caipiras, e falam do Brasil com patriotismo ufanista. Houve um imenso debate em torno do Jeca Tatu, principalmente após conferência de Rui Barbosa, na qual este consagra Monteiro Lobato, mas questiona a representação do Brasil como um país de Jecas Tatus.

Após sua adesão à campanha do saneamento rural, Lobato reescreve seu julgamento do caipira paulista: o Jeca não é 
vadio, está doente. Às doenças apontadas por Belisário Pena em Saneamento do Brasil - malária, doença de Chagas e ancilostomose -, Lobato acrescenta a sífilis e o alcoolismo. Em seu livro $O$ Problema $V i$ tal analisa o comportamento do Jeca à luz da saúde pública e defende a campanha sanitária liderada por Miguel Pereira, Belisário Pena e Artur Neiva. Publica então o Jeca Tatuzinho, uma espécie de folhetim no qual narra a história do Jeca que, depois de se curar da ancilostomose, torna-se um apóstolo da higiene e do progresso. "Livre da opilação e, como conseqüência, do estado de permanente desânimo, torna-se produtivo e, em pouco tempo, um próspero fazendeiro, competindo com seu vizinho italiano e rapidamente ultrapassando-o. Mais do que isso: modernizou sua propriedade, introduziu novas lavouras e tecnologia e aprende a falar inglês" (Lima, 1999, p. 147). Assim o novo Jeca, agora rico, torna-se educador sanitário. Foi esse texto que se tornou peça publicitária do Biotônico Fontoura nos anos 1920.

O caipira tratado por Lobato na figura do Jeca Tatu teve assim duas versões - o de cócoras e o doente (5). O Jeca de cócoras, com sua preguiça, foi trabalhado e discutido por Mário de Andrade em Macunaíma, personagem que também ironiza o discurso sanitarista, assumido por Lobato, na célebre frase: "Muita saúva, pouca saúde, os males do Brasil são" (Lima, 1999, p. 144).

Os textos de Lobato, assim como a polêmica em torno do Jeca, passam a compor uma tradição na forma de tratar o caipira no Brasil. Nela há um tom que ressalta a precariedade, o ridículo daquele matuto, principalmente quando ele vai para a cidade grande. Se isso já existia na comédia romântica de um Martins Pena, o Jeca de Lobato dá continuidade a essa tradição que, mais tarde, é também retomada no cinema de Mazzaropi (Lajolo, 2000, p. 26).

Enquanto o Jeca preguiçoso ou doente aparece nas páginas do jornal e do livro de Lobato, é apresentada no Teatro Municipal de São Paulo, em 1919, a peça de Afonso Arinos, O Contratador de Diamantes. Baseada em episódio considerado verídico acontecido no Tijuco, hoje Diamantina, entre 1751 e 1753 , a peça trata de forma simplista diferentes tipos sociais, entre eles "tipos populares, marcados pela ação do meio, portadores e geradores de uma cultura folclórica particular" (Berriel, 2000, p. 73). Subjacente a seu enredo, há uma busca da genealogia que tornava os paulistas os fundadores da pátria. Confirma-se uma mitologia da identidade nacional cuja matriz está na bandeira e no paulista. Em sua apresentação, pela primeira vez vê-se no palco uma dança folclórica brasileira - um congado - interpretada por "pretos de verdade" e por dançadores e violeiros da roça.

Afonso Arinos, representante do regionalismo, do conto sertanejo, encanta a elite da época. Amigo de Catulo da Paixão Cearense, o autor fazia apresentações do "cateretê" em seu palacete paulista e é lembrado como importante mediador entre as culturas erudita e popular, entre os mundos cosmopolita e regional.

A apresentação do Contratador de Diamantes indica o movimento literário regionalista que está em curso no início dos anos 1920 em São Paulo e que se dedica à vida rural e à cultura caipira, exemplificado nos saraus em que são apresentadas canções sertanejas com cantadores e violeiros nas mansões dos endinheirados. Mais do que valorizar o índio - vestígio do romantismo -, tratava-se então de valorizar o mameluco e seu representante contemporâneo - o caipira. A literatura ficcional da época estava à procura das raízes nacionais, ocupada em buscar uma autenticidade nacional localizada no homem do interior, no folclore, nos mitos de origem.

O regionalismo literário, do qual Afonso Arinos é um expoente, recebeu também o epíteto de "Velha praga" e foi considerado durante muito tempo pela crítica literária brasileira uma categoria ultrapassada. Retomado em meados do século XIX, o regionalismo fazia viver uma tensão entre o idílio romântico e a representação realista do homem docampo, entre a nostalgia do passado e a denúncia das misérias do presente.

"A história do regionalismo mostra que ele surgiu e se desenvolveu em conflito com

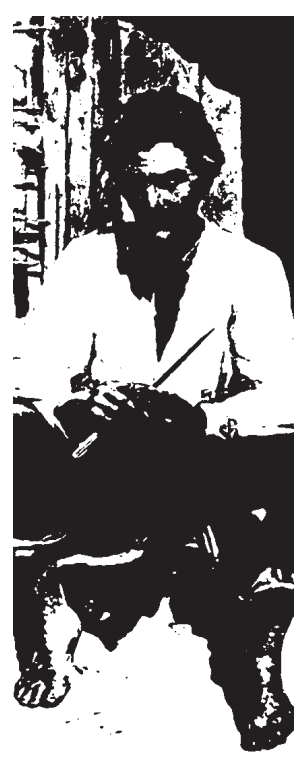

5 Segundo Mariza Lajolo, há ainda uma terceira versão do Jeca, rebatizado de Zé Brasi nos anos 1940 
a modernização, a industrialização e a urbanização. Ele é, portanto, um fenômeno moderno e, paradoxalmente, urbano", nos diz Ligia Chiappini (1995). A primeira geração modernista saudou a modernizaçãoe, em seu entusiasmo um tanto ingênuo, fez do regionalismo o principal alvo a atacar. "Daí o ataque violento do próprio Mário de Andrade ao regionalismocomo ‘praga nacional', juízo que ele iria relativizar na maturidade."

Em seu texto, Ligia Chiappini nos mostra como a literatura tende a recontar o processo de reajuste da economia brasileira aos avanços do capitalismo mundial ora como avanço, ora como decadência, ora com otimismo, ora com pessimismo. Ou seja, ora do lado da modernização, ora da ruína. O regionalismo foi muitas vezes confundido com a etnologia e com o folclore, e é avaliado negativamente, a não ser quando aparecem grande nomes e obras que conseguem elevar o regional ao universal como Guimarães Rosa e seu Grande Sertão: Veredas. Entre seus defeitos é apontado o de ser pitoresco, apresentar a cor local, ser descritivista. Para Ligia Chiappini, o regionalismo, além de falar do espaço geográfico do homem rural, envolve tornar
Caipira Picando Fumo, de Almeida Júnior

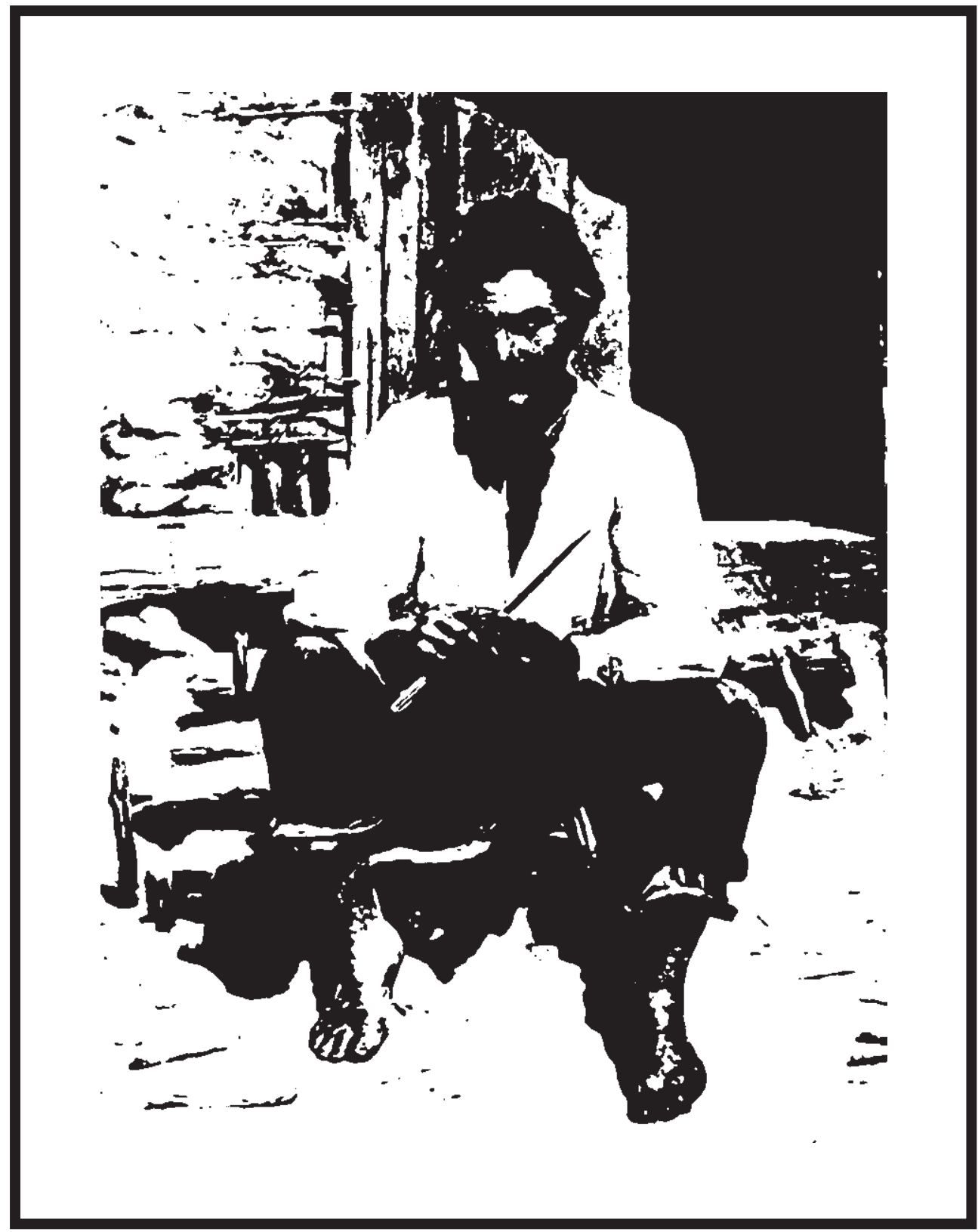


verossímil a fala de um outro, de classe e cultura diferente da do autor, que deve ser capaz de apresentá-la para um público citadino. O importante, diz a autora, é ver como o universal se realiza no particular compreendendo a função que a regionalidade exerce. Assim, é necessário relativizar os juízos críticos estereotipados sobre o regionalismo, essa literatura que trata do homem rural. Essa pertinente observação de Ligia Chiappini serve não só para a análise literária, mas também para as análises produzidas pelas ciências sociais.

\section{A SOCIOLOGIA DO CAIPIRA: ESQUECIDA OU REJEITADA?}

Quando a sociologia se debruçou sobre as relações sociais no campo, tinha em mente a comparação com a cidade, e sua análise veio apontar características muito distintas na maneira de viver do homem rural. Sua forma de produzir, suas relações sociais, suas regras de vida não eram escritas (não eram abstratas nem formais), e tudo isso apontava para a especificidade de seu mundo. Os habitantes do campo pareciam viver em um ritmo próximo da natureza. A avaliação variava entre exaltar sua sabedoria e expor seu atraso.

Foi a partir dos anos 1950, quando o mundo rural estava passando por profundas mudanças, que a produção sociológica se dedicou a estudar as dimensões da resistência dessa parte da sociedade frente ao processo de urbanização e industrialização. Supunha-se que os modelos industriais e urbanos iriam vencer de forma definitiva o campo. "Esse destino parecia traçado porque a cidade tinha tudo para oferecer ao campo e este nada tinha que pudesse servir à cidade. Seus modelos produtivos e socioculturais podiam continuar interessantes para alguns poucos cultores da história e do folclore, mas nem aos próprios agricultores interessavam mais" (Giuliani, s.d.). Essa tendência seria derivada do processo histórico, e o mundo rural ficava na coluna que significava atraso, tradição, sobrevivência. Em contraposição a ele estaria o mundo urbano, identificado como progresso, modernidade, futuro.

Esse contexto cultural talvez nos ajude a entender o "esquecimento" do livro Os Parceiros do Rio Bonito, de Antonio Candido, que analisa a formação histórica da cultura caipira no estado de São Paulo. Esse livro vem sendo recuperado recentemente e é considerado uma das mais importantes pesquisas sobre o tema. Apresentado como tese de doutorado de Antonio Candido em sociologia em 1954, foi publicado pela primeira vez em 1964.

O mundo caipira ali tratado era identificado com o Brasil arcaico e conservador que vinha sendo abordado principalmente pelos estudos de folclore. $\mathrm{O}$ fato de esse mundo tornar-se objeto da sociologia acadêmica que se desenvolvia no espaço das ciências sociais na USP constitui caso raro, acompanhado pelos trabalhos de Emílio Willems, de Maria Isaura Pereira de Queiroz e de Maria Sylvia de Carvalho Franco, entre outros.

A pesquisa de Antonio Candido é uma monografia antropológica sobre um grupo que habitava a fazenda Bela Aliança, em Bofete. A fazenda fora produtora de café e na época da pesquisa estava voltada para a produção de gêneros de subsistência sob o regime de trabalho de parceria. Oestudo trata do processo de urbanização em curso e das transformações na e da sociedade caipira. $\mathrm{O}$ caipira seria uma espécie de ponto médio entre o sitiante autônomo e o trabalhador assalariado. O estudo estabelece a relação entre a produção dos meios de vida e as formas de sociabilidade: por exemplo, a partir da produção da dieta alimentar, chega às dimensões da vida social. Assim, trata daquele grupo particular e ao mesmo tempo está interessado em entender a assimilação do caipira pela sociedade abrangente.

Antonio Candido faz uma "reconstrução histórica do caipira desde os primórdios da colonização em São Paulo, colonização singular porque, desde o século XVI, esteve voltada para a penetração do interior" (Jackson, 2001, p. 129). Suas principais 
fontes são os depoimentos de velhos caipiras; os relatos dos viajantes dos séculos XVIII e XIX; os textos de folcloristas como Amadeu Amaral e Cornélio Pires.

O autor faz uma descrição detalhada da vida do grupo e de suas transformações recentes. Utiliza o conceito de "culturas rústicas", como aquele meio social e cultural que exprime o universo das culturas tradicionais do campo no Brasil e é resultado do ajustamento do colonizador português ao contato com o índio. Essa cultura estaria mais próxima das culturas indígenas, já que se desenvolveu de maneira mais isolada. $O$ caipira seria assim o homem rústico da colonização paulista, aquele que se manteve marginalizado das interpretações mais amplas da formação histórica brasileira e que guardaria similaridades com o tipo que fora estudado por Euclides da Cunha - o sertanejo.

As origens da sociedade caipira advêm daqueles homens que abandonam as expedições exploradoras e se fixam no território do interior. Suas caraterísticas dependem da abundância de terras, da mobilidade constante e do caráter aventureiro do mameluco. São esses os traços que marcam sua particular adaptação ao meio ambiente, já que a ocupação do território é transitória e não inclui a propriedade. Sendo o povoamento disperso, é o "bairro" a unidade mínima da sociabilidade caipira; algo entre o povoamento urbano e o isolamento. A base da economia é o trabalho familiar completado pela ajuda dos vizinhos através do "mutirão", sistema de trocas entre os integrantes do bairro, que estabelece os vínculos sociais do grupo. O tempo do parceiro é regulado pelo trabalho na lavoura, onde importam o dia, a semana e o ano agrícola e, como já mencionamos, a dieta, marcada pelo feijão, arroz e milho. A dieta mostra-se pobre e mal equilibrada, ao contrário do que diziam folcloristas como Cornélio Pires.

O caipira dependia da mobilidade e da terra abundante para resolver sua adaptação precária ao meio ambiente. Agora isso se tornava cada vez mais difícil. O mundo se transforma, se fragmenta e não se man- tém mais a interpenetração entre trabalho, lazer e religiosidade, como era comum na cultura rústica caipira. "A cultura caipira caminha para o fim inevitável, mas revela ao mesmo tempo formas de resistência" (Jackson, 2001, p. 132). Sua repulsa ao trabalho assalariado constitui uma dessas reações; outra é a mobilidade espacial enquanto for possível. A grande questão é: como incluir as populações rústicas na urbanização acelerada que está em curso no Brasil e principalmente em São Paulo?

Por outro lado, pode-se indicar que o tex to de Antonio Candido está inserido em uma tradição que vai de Capistrano de Abreu, passa por Paulo Prado e chega a Cassiano Ricardo, para citar os autores mais conhecidos que valorizam a especificidade da colonização no planalto paulista, marcada pelo isolamento e voltada para o interior. Essa mesma tradição também está presente em Sergio Buarque de Holanda (Dias, 1987).

O caipira de Antonio Candido pode ser considerado descendente daquele bandeirante tratado por José de Alcântara Machado em seu livro Vida e Morte do Bandeirante (1929). Esse autor analisa os inventários do período 1578 a 1700 do primeiro Cartório de Órfãos da capital e dali infere um "bandeirante pobre e analfabeto, grosseiro de modos e de haveres parcos, vivendo quase na indigência, duro para consigo mesmo e com os semelhantes, austero e primário, em luta permanente contra dificuldades de toda espécie”, como diz Sérgio Milliet na introdução do livro.

José de Alcântara Machado, em Vida e Morte do Bandeirante, desmistifica aspectos que tinham sido retomados e difundidos por Oliveira Vianna em Populações Meridionais: São Paulo como cidade habitada por nobres refinados e cultos. Essa versão não pôde sobreviver à vista dos inventários e testamentos dos paulistas do século XVII, publicados no governo Washington Luís. José de Alcântara Machado, pai de Antônio de Alcântara Machado (6), estudou as fortunas, o povoado, o sítio da roça, o vestuário, as doenças e os remédios, a organização da família e a escravaria, 
a religiãoe o comportamento diante da morte. Para ele, a mistura do sangue de um povo de marinheiros como sangue de tribos errantes produziu um homem pobre, analfabeto, de modos grosseiros, mas com toque de austeridade e de heroísmo. A contribuição de José de Alcântara Machado foi a de recriar o bandeirante como um homem comum.

A figura do homem comum continuou a ser estudada pela historiografia. Sergio Buarque de Holanda dedica vinte anos de seu trabalho para estudar a adaptação do português ao Novo Mundo em seu livro Caminhos e Fronteiras, publicado em 1957. Estuda a adequação dos bandeirantes às técnicas indígenas observando aspectos do cotidiano da fronteira, especialmente os caminhos e a caça. A dieta alimentar também merece atenção especial: o milho nativo, o trigo e o arroz introduzidos pelos adventícios. Analisa o uso da farinha de mandioca, o "pão da terra", e como as máquinas e técnicas de moagem usadas no trigo passam para o milho. O que importa destacar aqui é como seus estudos analisam a recuperação do legado europeu e o amálgama formado com recursos e técnicas indígenas. Sergio Buarque, segundo Robert Werner, analisa o transplante de uma cultura européia marcando suas circunstâncias especiais e o papel da fronteira nesse processo. No primeiro momento, diante do ambiente hostil, o colonizador se adapta ao nativo; em um segundo momento retoma sua tradição, que passa a se amalgamar com a tradição de origem nativa. Só em um terceiro momento há a retomada do legado europeu em novas bases (Werner, 2000, p. 215).

Os estudos de Sergio Buarque de Holanda sobre a fronteira permitiram uma saída diante dos impasses apresentados pelo autor em Raízes do Brasil. "Os homens que conquistaram as fronteiras [expressavam a] - mentalidade que conta com certa 'dose de previdência, virtude eminentemente burguesa' e, ao mesmo tempo, com uma "noção romântica e feudal de lealdade", (Werner, 2000, p. 220).

A sociedade rústica foi constituída nos interstícios da sociedade colonial brasileira, centrada no latifúndio exportador, e não resultou da decadência do latifúndio. As populações rústicas mereceram a atenção de Maria Isaura Pereira de Queiroz, de Maria Sylvia de Carvalho Franco e de José de Souza Martins, ocupados em pensar o mundo rural a partir das mediações com a sociedade abrangente em processo de modernização (Jackson, 2002, p. 95). Nesse sentido, esses autores realizaram uma crítica aos chamados "estudos de comunidade" stricto sensu, cujos principais representantes foram Willems e Wagley. Quais eram as condenações explicativas aos "estudos de comunidade"?

Maria Isaura Pereira de Queiroz afirma a existência do "campesinato brasileiro" e, em Bairros Rurais Paulistas, observa a existência de diferentes tipos de bairros, o de camponeses e o de agricultores. Para ela, "a sobrevivência do caipira sempre dependeu [...] do equilíbrio obtido na relação estabelecida com a sociedade global" (Jackson, 2002, pp. 97-8). Ela aponta para a cultura de imigrantes e descendentes assimilados ao modo de vida e ao folclore caipira, o que permitiria a ampliação das bases da civilização rústica.

Retornando aos trabalhos de Maria Isaura Pereira de Queiroz, verificamos que sua primeira observação em Bairros $R u$ rais Paulistas (1973) é que o estudo do meio rural brasileiro, e especialmente paulista, tem merecido pouca atenção dos pesquisadores. Sabe-se pouco como se organiza e como funciona a sociedade rural paulista. Entre os trabalhos que já se dedicaram ao tema, o de Antonio Candido, Os Parceiros do Rio Bonito, é seminal, e é a partir dele que a autora avança seus estudos. Foi ele quem delimitou o "bairro rural" como "unidade mínima de povoamento nas áreas rurais paulistas, de nível econômico bastante precário, entrando em decadência muito facilmente e parecendo fadado à degradação social ao sofrer o impacto da industrialização ora em processo no estado" (Queiroz, 1973, pp. 1-2).

O trabalho de Maria Isaura é uma conversa contínua com o de Antonio Candido, e nele a autora procura avançar no entendimento dessa realidade concordando em 


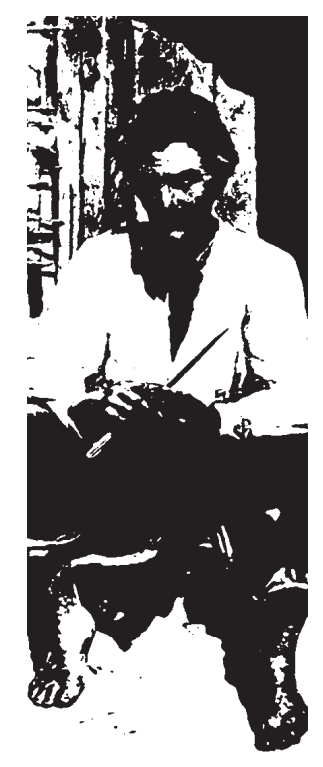

muitos pontos com o autor e divergindo em outros. Diria que seu ponto principal tem a ver com a questão: estaria realmente o pequeno proprietário condenado à desorganização socioeconômica ou era possível seu reerguimento?

O bairro, como forma elementar de sociabilidade rústica, tinha alguns traços básicos, entre eles o isolamento e o "sentimento de localidade”. Sua caracterização mostra que nele o produtor consome o que produz, não visa ao lucro com o cultivo da terra. $O$ lavrador, o camponês, vive do que produz e utiliza o que não usa para troca ou venda. $\mathrm{O}$ agricultor, diferentemente, produz para um mercado local, regional ou internacional, e seu objetivo é o lucro; em geral se especializa no cultivo de um ou dois produtos. $\mathrm{O}$ bairro rural tratado por Antonio Candido é composto de camponeses que podem ou não possuir a terra em que trabalham. Não é a situação em relação à propriedade da terra o que os qualifica, e sim a situação de pequenos produtores independentes.

A civilização rústica, como chamou Antonio Candido, constitui a antiga civilização formada no Brasil pelo contato dos portugueses com a nova terra, pela sua adaptação à vastidão tropical, pelos processos de aculturação entre as heranças culturais de brancos, índios e negros. Essa civilização teve e tem uma conservação notável; seus traços tiveram tal persistência que atraiu a atenção dos pesquisadores das ciências sociais interessados pela continuidade de elementos folclóricos (Queiroz, 1973,p. 7). Entendida como sobrevivência de épocas remotas, a civilização caipira existiria em áreas do estado resultantes do povoamento mais antigo.

Historicamente, a civilização caipira foi dominante até o século XIX, embora no século XVII já sofresse mudanças decorrentes do aparecimento de grandes plantações de cana orientadas para a exportação do açúcar. Essas mudanças foram se intensificando com as fazendas de café no século XIX, que produziram o primeiro abalo sério na civilização caipira; em seguida veio a industrialização, fazendo desaparecer a civilização caipira nas regiões da grande propriedade onde trabalhavam os imigrantes europeus recém-chegados. A disseminação da grande propriedade e a industrialização teriam sido responsáveis pela difusão de uma civilização urbana moderna de efeito devastador sobre o mundo rural tradicional, aquele dos "bairros paulistas".

Maria Isaura Pereira de Queiroz vai se dedicar ao estudo de diversas localidades, de bairros específicos no interior paulista, procurando responder às questões que a literatura dos anos 1960 e 1970 apresentava. No que nos interessa, vale citar suas pesquisas sobre o bairro de Taiquiri, situado no município de Leme, do antigo Oeste paulista. Sua descrição persegue a distribuição da propriedade; as principais culturas e sua produtividade; a utilização de arados; a existência de associação rural; o trabalho assalariado e o meeiro; o tipo de casa; o trabalho de colheita; a ajuda mútua; as tensões; as disputas entre famílias; o comércio local; o núcleo central do bairro; a organização da família; a herança; o compadrio; os equipamentos de educação e saúde; a organização política e os “cabos eleitorais".

Se a vida política é quase inexistente, a vida religiosa é muito intensa, e pode-se observar a sobrevivência de certas danças folclóricas como parte das festas religiosas. Isto, nos diz a autora, "num bairro cujos habitantes são também descendentes de imigrantes italianos" (Queiroz, 1973, p. 43).

No caso particular de Leme e Taiquiri, não se observa distância notável entre a vida urbana e a vida rural, e nesse bairro encontram-se basicamente agricultores, que vivem da venda dos produtos. Assim, do ponto de vista apenas econômico, esse bairro não comporia a sociedade ou civilização rústico/caipira. Entretanto, outros traços marcam o grupo. "É de notar que, num bairro cujos moradores são em sua maioria de ascendência italiana, continuam vivos e apreciados elementos folclóricos de origem portuguesa e brasileira, como a Dança de S. Gonçalo e o cateretê. Fenômeno evidente de aculturação, alia-se a um fenômeno de continuidade folclórica que deve ser ressaltado também" (Queiroz, 1973, p. 48). 
As relações familiares, as relações vicinais e as relações de trabalho continuam semelhantes às dos bairros tradicionais e se expressam na importância da ajuda mútua, do compadrio, das festas religiosas. A pouca estratificação social, com uma situação mais igualitária, também marca a vida social do bairro, somando-se ao sentimento de localidade. "Ao 'sentimento de localidade', de que fala Antonio Candido, ajuntamos a igualdade de posição social entre as famílias, que rege as relações entre elas, a participação delas na vida da comunidade, e as relações de trabalho" (Queiroz, 1973,p. 49).

A possibilidade de conservação dos aspectos folclóricos tradicionais está ligada às relações sociais em vigência. "A adoção do folclore luso-brasileiro por famílias de origem italiana é fenômeno que merece estudo. Pode-se pensar que, constituindo a festa religiosa um dos fatores mais importantes de integração de famílias e indivíduos de fora, na vida e na estrutura do bairro [...], a aceitação pelos descendentes de imigrantes, de traços folclóricos que compunham a festa tradicional, teria sido uma das maneiras deles se inserirem no grupo vicinal. É lícito supor, pois, que o folclore desempenharia, nos bairros rurais, importante função de incorporação social dos adventícios"(Queiroz, 1973, p. 50).

Maria Isaura, nesse seu texto, observa a intercessão entre o mundo do imigrante e o universo caipira, questão que foi pouco trabalhada pelas ciências sociais. Por outro lado, o imigrante e sua família são atores sociais tão "tradicionais" quanto aqueles pertencentes à cultura caipira aqui encontrada. Nesse sentido, não há diferença substancial entre o camponês do sul da Itália e aquele do interior paulista, mesmo que suas manifestações folclóricas sejam distintas.

Sua observação subseqüente também nos ajuda a entender a disseminação do universo caipira para além de seus locais de origem: "A aculturação das famílias italianas, transformando-lhes o acervo cultural que possuíam, faz com que, ao se estabelecerem em zonas recém-desbravadas, aí possam implantar elas mesmas resquícios da civilização tradicional caipira. Elas se transformam em veículos desta civilização “(Queiroz, 1973, p. 50). Os próprios descendentes de imigrante poderiam ter servido como veículos de difusão, fazendo a sociedade tradicional renascer em outros pontos distantes do estado, graças ao êxodo das zonas velhas para as zonas novas... Essa questão é apontada pela autora, ressaltando que esse processo de aculturação ainda não foi suficientemente pesquisado. “A adoção de traços específicos por indivíduos estranhos à civilização caipira" se explicaria pelo desejo de integração...

"Levado por descendentes de imigrantes, o folclore pode se ter espraiado muito além das regiões em que nasceu e viveu até meados do século XIX a civilização caipira. A invasão de certas zonas do Estado por elementos vindos de fora não desenraíza tais práticas" (Queiroz, 1973, p. 136).

A base em que tais traços se apóiam, e que permitem sua continuidade, é constituída pela organização social especial dos grupos de vizinhança. Onde estes entram em decadência, as práticas folclóricas tendem a desaparecer. Onde a organização tradicional se mantém, o folclore permanece, desde que haja indivíduos interessados em sua prática. $O$ isolamento não é assim o elemento fundamental da continuidade do folclore, e sim a organização social específica. A proximidade de uma grande cidade pode agir ora como fator de desorganização, ora como fator de conservação. A disseminação de grandes fazendas monocultoras numa área de bairros rurais é fator de decadência para eles, tanto quanto o desenvolvimento das cidades

Como parcelas dos excluídos europeus, os "camponeses" se amalgamaram à sociedade e cultura dos caipiras, os excluídos daqui. Em Maria Isaura, os descendentes dos imigrantes se aculturaram nos bairros rurais paulistas e, ao se deslocar, carregaram os traços culturais tradicionais. A mobilidade, longe de apagar a tradição, faz aumentar sua área de atuação. Se, em suas pesquisas da década de 1960, publicadas em 1973, Maria Isaura está levantando essa hipótese, temos, mais recentemente, Ruben Oliven (1992) nos mostran-

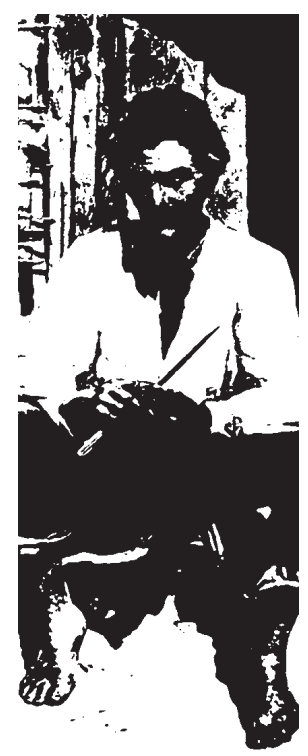


do o processo de disseminação da cultura gaúcha por diferentes espaços da fronteira agrícola do país.

A junção entre imigrantes, construção de uma tradição e difusão cultural pode ser observada na pesquisa de Ruben Oliven ao examinar os Centros de Tradição Gaúcha. Em 1948 é criado em Porto Alegre o “35 CTG”, o primeiro Centro de Tradições Gaúchas, cujo nome evoca a Revolução Farroupilha de 1835. Ele será modelo para centenas de outros no Rio Grande do Sul e em outros estados. Seus fundadores eram, em sua maioria, jovens interioranos que foram estudar em Porto Alegre, descendentes de pequenos proprietários rurais, quase todos com sobrenomes de origem lusa.

Já o segundo CTG teve por fundadores adultos de origem alemã oriundos de área de colonização com base na agricultura familiar em pequena propriedade. Em sua explicação diante desse "fenômeno estranho" Ruben Oliven observa que no tradicionalismoé exaltada a pecuária, ao passo que a agricultura era quase vista como atividade degradante. Ser colono, ao nível das representações, significava sobretudo ser carente de certos atributos - ambição, traquejo social-positivamente considerados (Oliven, 1992, p. 80). Os imigrantes estrangeiros, por sua vez, idealizavam o gaúcho como tipo socialmente superior. Assim, se identificar como "gaúcho" significava, para o colono, "uma forma de ascensão social” (Oliven, 1992, p. 81).

O movimento tradicionalista consegue se "expandir" dentro da burocracia do estado e cresce principalmente nas cidades do Rio Grande com a realização de festas, rodeios, festival de músicas, que reúnem jovens que ficam acampados evocando a vida campeira e os símbolos de uma identidade regional gaúcha (Oliven, 1992, p. 87).

A expansão do tradicionalismo para fora do Rio Grande pode ser entendida se acompanhamos a emigração dos gaúchos, saídos principalmente do interior do estado para o interior de outros estados. Em 1980 havia aproximadamente 900.000 vivendo fora do estado, o que equivale a $11,5 \%$ de sua população e torna o Rio Grande do Sul o estado de maior emigração do Brasil. Essa dispersão populacional se fez presente na criação de CTGs por regiões de expansão no extremo oeste de Santa Catarina, no Paraná e no Mato Grosso do Sul, onde havia 35 CTGs.

"Os colonos que emigraram do Rio Grande do Sul e foram se estabelecer em outras unidades do Brasil, ao cultuarem os costumes e valores das estâncias da Campanha, estão fazendo referência ao mundo ao qual na verdade jamais pertenceram. Ao saírem do estado, onde eram no máximo proprietários de apenas alguns hectares de terra, e adquirem glebas bem maiores em áreas de fronteira agrícola, eles simbolicamente deixaram de ser pequenos colonos e transformaram-se em grande fazendeiros, isto é 'gaúchos"' (Oliven, 1992, p. 92).

Dentro do tema do contato entre o imigrante, o camponês estrangeiro e o caipira paulista, vale notar a importância da pesquisa realizada entre 1960 e 1968 por João Baptista Borges Pereira, publicada no livro Italianos no Mundo Rural Paulista (2001). $\mathrm{O}$ autor trabalha, entre outras fontes, com depoimentos de imigrantes italianos que se dirigiram para Pedrinhas, núcleo próximo da cidade de Assis, em São Paulo. Comunidade planificada pela Companhia Brasileira de Colonização e Imigração Italiana, criada em 1950, Pedrinhas criou a imagem de ser um villaggio italiano no interior paulista. A localidade se torna município em 1991 e, em 2001, tem uma filha de imigrante italiano como prefeita, como nos informa o autor no prefácio da segunda edição do livro. A pesquisa de João Baptista apresenta pontos a serem ressaltados: trata-se de uma imigração recente (dos anos 1950); de uma imigração para o mundo rural; de uma imigração controlada pela criação e implementação de uma colônia. $\mathrm{O}$ autor conseguiu acompanhar, em seu estudo, quase que o "instante histórico" em que se dava a imigração e o processo de aculturação estava acontecendo.

Ao procurar dar conta do grupo migrante, João Baptista chama a atenção para o número restrito de trabalhos que apresentam as 
variantes socioculturais da Itália e cita, por outro lado, os poucos estudos sobre o mundo rural no Brasil. Ao lidar com as duas culturas e com o processo de aculturação, observa serem elas culturas aparentadas, mas que apresentam diferentes nuanças.

A Itália, observa o autor, é um país de emigração. Lá se justifica e se estimula a emigração, são favorecidas as atitudes que permitem enfrentar os deslocamentos. Há o "inculcamento desses valores no plano da personalidade [que se traduz] na generalizada 'vontade' de emigrar, de que é portador o italiano" (Pereira, 2001, p. 41).

No depoimento de um chefe de família sobre sua vinda, apresentado no livro, observa-se o desconhecimento sobre o Brasil: "Vim para o Brasil preparado para lutar com cobras e bichos gigantescos, mas não sabia o que fazer com a saúva que comia tudo que eu plantava" (Pereira, 2001, p. 66). Observam-se as tensões na chegada, a reação ao isolamento da colônia (os imigrantes viajaram 21 horas de trem de São Paulo até Assis). O italiano reage ao diferente: valorizava a montanha, enquanto o paulista valorizava a terra roxa; há diferenças de padrões higiênicos; há o estranhamento de cheiros e gostos.

Foi na colônia que o imigrante incorporou a mecanização da lavoura, já que vinha de uma Itália arruinada pela guerra. O aumento de seu poder aquisitivo é associado ao Brasil e às condições de ser bemsucedido. Então ele apreende um estilo de vida mais urbano, e isso o distancia tanto do estilo de vida do mundo rural italiano quanto do brasileiro. Os italianos vão compondo uma imagem negativa do brasileiro rural, relacionada à chegada da mão-deobra nordestina, que vai ocupar posição inferior naquele grupo; são empregados do patrão italiano.

O imigrante do núcleo de colonização teve sua vida econômica sujeita ao planejamento, que envolvia o uso racional do solo. Ele reagiu a isso, já que na Itália não estava acostumado a métodos racionais de agricultura. Esse padrão já estava implantado em São Paulo, e seus resultados já se faziam sentir na agricultura dos japoneses, que conseguiam aproveitar bem terras de baixa qualidade. Os valores da região, presentes na influência da cidade, na busca do lucro, do dinheiro, do poder econômico, fazem o italiano aceitar o uso de métodos racionais de agricultura, que envolvem apoio técnico e mecanização da lavoura.

O trabalho vai mostrando como aquele grupo inicial se adapta, mantém valores, troca valores, acopla valores novos a velhos. Internamente o grupo também se diferencia entre os do norte e os do sul. Em Pedrinhas repete-se a visão preconceituosa já existente na Itália sobre a cultura do sul - ligada à vendetta e ao crime. Os do norte são vistos como superiores, mais inteligentes, mais higiênicos, mais progressistas, mais civilizados, racialmente mais puros. Os do sul carregam a visão negativa de serem inferiores, menos inteligentes, mais adequados aos trabalhos braçais, mais atrasados, mais grosseiros, supersticiosos. Ao que, observa o autor, reproduz-se com os meridionais o que ocorre com o negro entre nós (Pereira, 2001, p. 159).

"O trabalhador brasileiro, com mentalidade pré-capitalista, tem um comportamento que colide em vários pontos com o do homo oeconomicus" (Pereira, 2001, p. 163). Ele vê o italiano como sovina, individualista, interesseiro, egoísta, argentário; este vê os brasileiros como apáticos, imprevidentes, sem ambições e sem vontade de progredir.

A Igreja, junto com as pessoas mais velhas, é um foco de resistência às mudanças e preserva as tradições italianas. A escola e as gerações mais novas são as forças de renovação. A Igreja é mantenedora da tradição e ao mesmo tempo combate comportamentos da Itália atrasada. Há no livro uma descrição dos rituais fúnebres das populações do sul da Itália que são considerados atrasados pela Igreja e pelos italianos do norte (Pereira, 2001, p. 212).

A sociabilidade do grupo se desenvolve no plano da família e da vizinhança. Há um reforço da tendência endogâmica e,com esta, dos laços de parentela. A família constitui uma unidade de produção e de consumo. A vida associativa se dá na família 


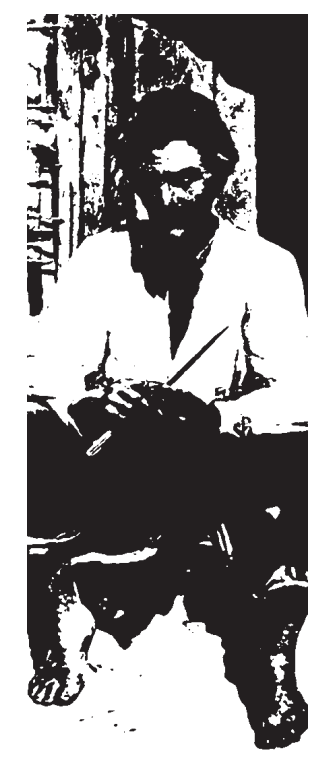

extensa, composta de famílias nucleares de mesmo tronco, no que se assemelha à família patriarcal bem conhecida no Brasil. A família patriarcal, organizada por assimetria, envolve a subordinação dos mais jovens aos mais velhos e das mulheres aos homens. Isto é italiano e também é brasileiro. Mas, ressalta o autor, há nuanças nos comportamentos do norte e do sul quanto ao papel da mulher. A mulher mais velha, esposa ou viúva do capo, atua sobre todas as demais dentro do grupo. Há reação ao casamento misto, à quebra de padrões endogâmicos, já que permitiria a entrada de mulheres de fora, que não aceitariam obedecer à sogra e morar com a família do marido. Assim, o padrão é procurar casamento com pessoas da mesma localidade, da mesma província, da mesma região e, por fim, da Itália.

São os padrões de transmissão da herança que são ameaçados quando da presença de cônjuge brasileiro (Pereira, 2001, pp. 203-5). Este ameaça o costume histórico de preservar intacto o patrimônio do grupo através da passagem da herança para o filho mais velho; ou de beneficiar somente os filhos, dando às filhas apenas alguns bens que as façam aceitar a partilha unilateral. Essa tradição italiana também existe na Península Ibérica sob o nome de morgadio. No Brasil a tradição jurídica é diferente e se choca com esse costume (ainda que a legislação italiana já tivesse sido alterada). Genros e/ou noras brasileiros ameaçam tudo isso.

Os valores econômicos do imigrante têm grandes afinidades com os valores daquela área - mentalidade pioneira, apologia do self-made man, do homem ousado, quase aventureiro. Mas, anota o autor, esses valores se referem ao grupo familiar como unidade de produção e consumo, e não ao indivíduo. Em sua contabilidade econômica o italiano valoriza tudo que o faça "ganhar tempo", e é nesse aspecto que aceita substituir elementos da cultura italiana por outros que sejam mais adequados à realização de seus objetivos. Vive mais preocupado com o futuro do que com o passado. O que legitima o status mais alto não é a his- tória, mas o sucesso. Tudo isso corresponde aos valores daquela área que vive a mística do progresso associado ao tempo futuro. Quando indagados sobre a razão do sucesso, respondem atribuindo-o às qualidades do povo italiano, às figuras heróicas que primeiro enfrentaram a ocupação da região, aos pioneiros.

João Baptista Borges Pereira presta sua homenagem a Emilio Willems, a Egon Schaden (o trabalho é dedicado a ele) e a Pierre Monbeig, mas procura "esclarecer, logo de início, que este não é trabalho que pretende serclassificado, metodologicamente, como "estudo de comunidade"' (Pereira, 2001, p. 26). Nessa pesquisa sobre os italianos que foram para o mundo rural brasileiro está presente, portanto, um traço comum das ciências sociais da época. Por que esse autor, assim como outros aqui citados, se apressa a esclarecer que não está fazendo "estudo de comunidade"? O que era isso?

Como nos diz Donald Pierson, a comunidade é constituída por grupos que surgem da simbiose, do fato de viverem juntos. A comunidade é o objeto central do campo denominado ecologia humana (estudos das relações humanas influenciadas pelo habitat e influenciando o espaço). Competição, conflito, acomodação e assimilação estão entre as categorias básicas para a análise da interação social. Controle social (ou seja, de mecanismos de ordenamento dos conflitos), distância social(do qual o preconceito é um tipo) e mudança social formam o elenco de questões e perspectivas que derivam da chamada sociologia de Chicago.

Donald Pierson, Herbert Baldus e Emilio Willems foram professores da Escola Livre de Sociologia e Política nos anos 1940. Na pós-graduação, criada em 1941, por exemplo, Pierson deu o curso Pesquisas Sociais na Comunidade Paulista e Willems, que também era professor da USP, ministrou o curso Assimilação e Aculturação no Brasil Meridional. O trabalho de Donald Pierson sobre Cruz das Almas e o de Emilio Willems sobre Cunha são as matrizes do que se constituiu como estudos de comunidade, ambos voltados para en- 
tender a pequena propriedade rural e a presença dos imigrantes naquela área.

Assim podemos dizer que há, sim, uma sociologia esquecida: a que trata dos caipiras. Ou melhor, essa sociologia era rejeitada. Ela está presente em Antonio Candido e seu Os Parceiros do Rio Bonito; Estudo sobre o Caipira Paulista e a Transformação dos seus Meios de Vida (1964); em Maria Isaura Pereira de Queiroz e seus Bairros Rurais Paulistas (1973) e O Campesinato Brasileiro: Ensaios sobre Civilização e Grupos Rústicos no Brasil (1973).

Retomando Antonio Candido, diz Maria Isaura Pereira de Queiroz na introdução de Bairros Rurais Paulistas que comunidade cobria realidades muito diferentes: “A comunidade de Willems é uma cidadezinha e seu território administrativo - seu município; a de Pierson, um povoado e seus arredores rurais; a de Wagley, uma cidade com os povoados que dela dependem, assim como uma área bastante vasta de população dispersa". A argumentação de João Baptista Borges Pereira também é de ordem metodológica, já que em seu trabalho "faltam-lhe, entre outras características, a representatividade da unidade escolhida para estudo e o interesse pela análise exaustiva de todas as manifestações da vida comunitária" (Queiroz, 1973,p. 26). Ecomplementa dizendo que nessa ressalva não há "quaisquer restrições a este método consagrado pela antropologia cultural; como também não representa endosso às críticas surgidas ultimamente entre nós a este recurso de análise" (Queiroz, 1973, p. 26) (7).

Em 1969, Maria Isaura Pereira de Queiroz organiza o volume Sociologia Rural da Coleção Textos Básicos de Ciências Sociais para a Zahar Editores. Em sua introdução ela faz um balanço da sociologia rural e aponta a existência de duas tendências: a francesa e a norte-americana. Esta última estaria "voltada para a prática imediata, que pretende dominar um aspecto considerado atrasado e insatisfatório da realidade social para promover nele uma mudança mais rápida no sentido da modernização". A francesa se norteia por indagações de tipo teórico, aborda os problemas do mundo rural numa perspectiva global questionando igualmente o urbano. A americana deseja acelerar a integração do mundo rural ao urbano, e a sociologia rural é um instrumento para isso. Daí a ênfase na difusão de novas técnicas e novos sistemas de valores no meio rural - trabalho conhecido como extensão rural.

Segundo Maria Isaura, o pressuposto de base da sociologia norte-americana é a igualdade fundamental do homem em todos os lugares. Psicologicamente idênticos, os indivíduos se comportam sempre movidos pelos mesmos desejos e aspirações. Com essas premissas consideram que o agricultor que adota as técnicas mais modernas é sempre mais racional do que aquele que não as adota. Esse quadro de referência permite a elaboração de pesquisas comparativas entre sociedades culturalmente diversas (Brasil, Nigéria, Índia) "selecionando "comunidades rurais' do mesmo tipo(!)" e aplicando os mesmos questionários a seus lavradores.

O questionamento básico apresentado pela autora tem a ver com o seguinte ponto: fatores de ordem cultural não se ligam sempre da mesma maneira aos fatos econômicos. Assim, “a difusão de técnicas não resultaria em homogeneização sociocultural, mas na criação de novas formas de civilização, provenientes de processos de sincretismo entre todo o acervo difundido e o acervo sociocultural existente na região".

O tema dos caipiras precisou de Maria Sylvia de Carvalho Franco, com seu livro Homens Livres na Ordem Escravocrata (1 edição 1969) para se inserir em um contexto histórico e intelectual considerado relevante pela elite acadêmica da USP. Esse trabalho foi tese de doutoramento da autora realizada em 1964. Sua banca e os amigos mencionados (8) formam a linha de frente das ciências sociais e da filosofia da USP até hoje. Na introdução a autora recomenda que se faça um esforço para "não renunciar aos conceitos inclusivos que apreendem conjuntos significativos de relações"; "evitar os esquemas escravismo-feudalismo-capitalismo"; e "não cair no artificialismo de fragmentar a realidade". E explicita sua linha

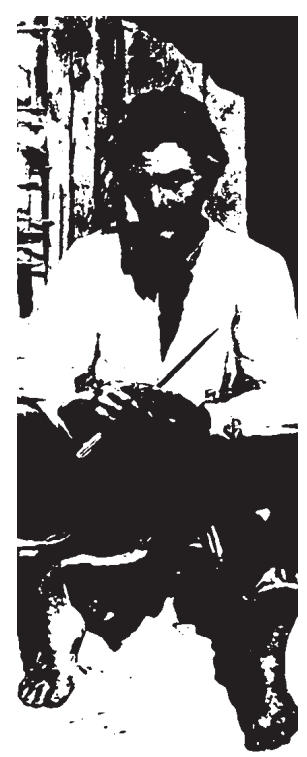

7 autor cita em nota, como exemplo das críticas, os tra balhos de Octavio lanni Maria Sylvia Franco Moreira [Carvalho Franco] e Oracy Nogueira.

Sua banca foi composta por Florestan Fernandes, Sergio Buarque, Antonio Candido, Francisco lglésias e Octavio lanni. Entre os amigos mencionados estão Marialice Foracchi, Roberto Schwarz Fernando Novaes, José Arthur Gianoti, Walnice Nogueira Galvão e Eunice Ribeiro. 
metodológica: "nas relações entre o mundo objetivo e subjetividade tomei por centro o conceito de práxis, que nos livra de velhos fantasmas como indivíduo e sociedade, personalidade e cultura" (Franco, 1974,p. 14). Para tratar o mundo dos homens livres, a autora diz haver uma "presença ausente" o escravo -, sem o qual não é possível compreender sua sorte.

Seu objeto é a velha civilização do café presente na área de Guaratinguetá e sua vizinhança, que exprimem a organização agrária colonial. Estuda as relações comunitárias do homem livre e pobre tomando como fonte os processos-crime da comarca da cidade. Daí a valorização da violência como cerne do "código do sertão", presente no primeiro capítulo. Seu estudo, diz a autora, observa a continuidade do "velho" para o "novo", uma rapidez nas transformações, em lugar das "resistências à mudança” que em geral se aponta (Franco, 1974, p. 16).

A densidade de seu texto merece uma análise que ainda não foi feita. Na literatura encontram-se muitas citações a esse texto, mas desconheço quem o tenha enfrentado. Eigualmente isso não será feito aqui. Quero apenas observar a posição de onde a autora fala: aluna/orientanda de Florestan Fernandes, a quem dedica o livro, membro de uma geração brilhante e fundadora das ciências sociais no Brasil. Uma autora dessa estirpe, "de esquerda", pode trazer o tema do homem pobre, do caipira, para o debate da formação social brasileira. Podemos aventar a hipótese de que esse livro funcionou para a sociologia do homem rural brasileiro do mesmo modo que Grande Sertão: Veredas para a literatura regionalista.

Houve, sim, um veto que, entretanto, não era o mesmo em todos os autores. Guerreiro Ramos, por exemplo, em Cartilha Brasileira do Aprendiz de Sociólogo, de 1954, onde reúne suas teses ou recomendações apresentadas no II Congresso Latino-Americano de Sociologia, de 1953, aborda o tema. Em sua quarta recomendação diz não ser aconselhável "aplicar recursos na prática de pesquisas sobre detalhes da vida social". Em outro texto sua crítica é mais explícita quando afirma ser injustificável a realização de trabalhos como Cunha: Tradição e Transição em uma Cultura Rural do Brasil, de Willems.

Sabemos que Florestan Fernandes e outros acadêmicos paulistas defenderam Willems dos ataques de Guerreiro Ramos, mas há também uma crítica que vem do grupo paulista, advinda das diferenças derivadas das matrizes e da escolas que se desenvolvem em São Paulo. A ELSP teve preocupações de ordem prática na sua criação, deveria produzir estudos que fornecessem base para políticas públicas específicas, dava ênfase a pesquisas empíricas e obviamente a cursos de métodos e técnicas de pesquisa, como derivava de seu modelo norte-americano. A USP propugnava um ensino mais humanista, destituído de qualquer finalidade utilitária, e seguia o modelo francês. A seriedade da ELSP, entretanto, atraiu muitos formandos da USP e fez a pesquisa empírica ser o atributo do sociólogo como profissional (Limongi, 1989).

A sociologia da mudança social trabalhou com o conflito entre civilização e "culturas de folk", linha de trabalho derivada da antropologia norte-americana que considerava a vida urbana como desorganizadora dos laços estáveis e homogêneos da vida rural e produtora de uma cultura fragmentada na sociedade urbana. O processo de urbanização, fonte de anomia e/ou modernização desejada, foi tratado pela sociologia da época com os conceitos de "demora cultural", de resistências, que se faz presente tanto em textos de Florestan Fernandes quanto nos trabalhos produzidos no Centro Latino-Americano de Ciências Sociais (CLAPCS).

Os entraves à modernização foram antes tratados por Emilio Willems, que introduz o conceito de "cultura rústica". "Não existe um sistema de entendimentos que possa servir de base comum à civilização urbana e à multiplicidade das culturas sertanejas", dizia Emilio Willems (9) ao estudar o problema rural brasileiro em 1944. A cultura cabocla é nômade, faz uso predatório da terra e dos recursos naturais. Tem uma existência vegetativa e é auto-sufici- 
ente. Seu modo de vida, chamado caipira, tem uma organização econômica pré-capitalista, alternativa única devido a determinadas circunstâncias. “A rejeição a esse princípio adaptativo por parte do imigrante levava-o a fracassar. E muitas vezes os 'italianos' e 'alemães' acaboclados sobreviveram e contribuíram para o povoamento dos sertões meridionais" (Willems, apud Lima, 1999, p. 174). Willems reconhece a necessidade da presença dos cientistas sociais nesse processo de mudança, já que eles seriam capazes de compreender os traços culturais e produzir mudanças, e não anomia. Observa que se sabe muito pouco para além das imagens literárias sobre a natureza das culturas caboclas.

Os trabalhos acima citados, de Antonio Candido, de Maria Isaura Pereira de Queiroz e de João Baptista Borges Pereira, produziram exatamente o que demandava Willems - conhecimento sobre o mundo e a cultura do homem rural. Seus estudos sobre aculturação e assimilação de imigrantes e sertanejos e suas propostas - pesquisa monográfica e estudos comparados - tinham como questão "assegurar maior uniformidade cultural e desenvolver mentalidade congruente com a economia e vida sociais modernas" (Lima, 1999, p. 176).

A natureza e o compromisso político das ciências sociais praticadas nos estudos de comunidade são explícitos. O estudo de Willems sobre o processo de mudança sociocultural em Cunha explora os processos de desorganização, de individualização e de secularização, ou seja, as tensões entre tradição e modernização. Seus estudos de comunidade estavam no campo da modernização do mundo rural brasileiro e partilhavam das premissas consideradas negativas ou problemáticas da sociologia norteamericana.

\section{AS NOVAS RELAÇOEES NO CAMPO}

A tendência predominante até pouco tempo atrás era ver apenas a cidade como lugar onde as transformações acontecem, onde a história se faz. O campo era o espaço das "sobrevivências", foco das "resistências" ao processo de modernização da sociedade brasileira.

Hoje isso não é mais assim. O trabalho de avaliação dos estudos sociológicos sobre o mundo rural vem sendo feito, e iremos mencionar aqui uma avaliação realizada por José Vicente Tavares dos Santos (1991). Segundo esse autor, foi a partir dos anos 1980 que "foi superada uma problemática relativa ao caráter global das relações sociais na agricultura, ou seja, a controvérsia sobre o feudalismo ou capitalismo como modo de produção dominantes no campo brasileiro" (Santos, 1991, p. 20). A sociologia rural trabalhava com visões polares tradicional/moderno ou rural/urbano. Pensava-se na passagem de comportamentos e atitudes "tradicionais" para "modernos" identificados como estilo de vida mais complexo, avanço tecnológico e mudanças em ritmo mais acelerado. "A dicotomia rural/urbano foi pensada em termos de uma urbanização do rural" (Santos, 1991, p. 30). Assim, o conhecimento na sociologia rural era produzido para superar o rural, como nos diz José de Souza Martins.

Essa matriz teve que ser alterada. Os processos sociais agrários em curso indicam a existência de um espaço social complexo, com grande diferenciação interna. Falar do Brasil rural hoje é assumir sua formação social capitalista dependente, marcada pela heterogeneidade social e regional, assim como pela exclusão de largos contingentes populacionais.

A reforma agrária dos anos 1950 e 1960 era pensada como distribuição de terras desapropriadas do latifúndio improdutivo. Nesse tempo, as pessoas saíam do campo e iam para as cidades em busca de trabalho. O que aconteceu no campo nos últimos trinta anos foi uma reforma agrária que estabeleceu relações de trabalho capitalistas com o assalariamento da mão-de-obra no campo e aumentou a produção. A solução econômica criou problemas sociais cada vez mais visíveis. Hoje são os excedentes urbanos desempregados que estão indo para o campo em busca de subsistência, e há 


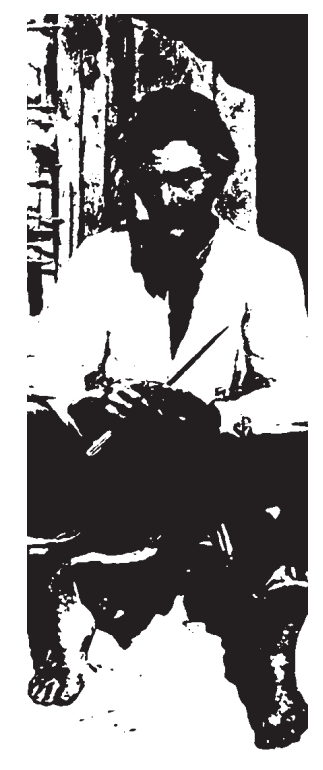

necessidade de expansão da produção para absorver a mão-de-obra tanto no campo como na cidade.

José Vicente Tavares dos Santos mapeia quatro eixos temáticos dos estudos sobre o rural, a saber: atuação do Estado; relações sociais no campo; violência, conflitos e lutas sociais; mediadores políticos atuantes nos processos sociais agrários. Em seu levantamento, o autor diz que ainda não temos um conjunto de estudos capaz de compor um mapa sociológico das relações sociais no campo. Observa também que "a classe social menos estudada, sob todos os pontos de vista, é a burguesia agrária" (Santos, 1991, p. 25). As classes dominantes no campo só são analisadas em sua dimensão de representação política, principalmente depois da criação da União Democrática Ruralista (UDR).

As políticas públicas têm sido analisadas em seus efeitos: sistema de crédito rural; institucionalização da pesquisa agropecuária (com a criação da Embrapa); centralização das atividades de assistência técnica e extensão rural (com a formação da Embrater); produção de bens de capital: maquinária e equipamentos, fertilizantes; fortalecimento de canais de comercialização; políticas de preços mínimos; criação do seguro agrícola e estímulo ao cooperativismo. A intervenção estatal no campo estimulou o crescimento intensivo da agricultura e implementou a política de colonização.

O tamanho e a visibilidade do campo brasileiro podem ser notados por suas festas. Segundo a revista Veja (maio de 1999), são realizados anualmente 1.389 rodeios, mobilizando um público de 2,7 milhões de pessoas e arrecadando 27 milhões de reais. A moderna indústria fonográfica relativa a esse segmento vendeu em 1998 cerca de 13 milhões de CDs. A Festa do Peão de Boiadeiro de Barretos ou a de Americana oferecem exemplos do sucesso atual. A mesma revista Veja (4 de junho de 2003) atualiza esses dados: o último levantamento sobre rodeios no Brasil diz que são 1.500 provas ao ano, que movimentam cerca de 2,5 bilhões de reais. O rodeio da cidade de Jagua- riúna atraiu 250.000 pessoas em seu último evento, e junto com o de Americana e o de Barretos, integra a trinca dos maiores do Brasil. Mesmo que essas cifras sejam discutíveis, elas procuram mensurar uma realidade que se impõe aos nossos olhos.

É esse novo mundo que, criado ou não pela ação das políticas públicas, não importa, vai ser mobilizado na criação de um novo imaginário, de uma nova identidade para o mundo rural.

Um dos trabalhos mais relevantes sobre a nova ruralidade brasileira é o de João Marcos Alem (1996). Ele aponta como se formou uma "rede simbólica da ruralidade", que se apresenta no vestuário, no consumo de artesanato, na decoração rústica, ou seja, no consumo de símbolos do mundo rural. Essa rede se faz presente em exposições, feiras, festas, rodeios, eventos esportivos, cívicos, religiosos, e recebe reforço de programas de rádio e $\mathrm{TV}$, da indústria fonográfica, de revistas, de suplementos de jornais e de peças publicitárias.

Esse processo de configuração cultural neo-ruralista, neo-sertaneja ou caipiracountry é encontrado nas regiões onde a modernização da produção rural foi mais intensa (Alem, 1996, p. 2). A nova ruralidade ultrapassou o mundo rural e atinge as cidades, principalmente as do interior. Apresenta-se no brilho das empresas e dos empresários, nas técnicas modernas de cultivo, nos artistas e nos peões de rodeios, pessoas e grupos cujos estilos de vida são muito distantes do Jeca Tatu de Monteiro Lobato, do sertanejo de Euclides da $\mathrm{Cu}$ nha, dos jagunços de Guimarães Rosa ou dos caipiras de Antonio Candido.

O início da modernização da agropecuária no Brasil esteve ligado ao movimento de extensão rural que, a partir de 1948, teve como missão educar e difundir tecnologia para o pequeno agricultor. De 1948 a 1980 se somaram a esse movimento o crédito subsidiado, a adoção crescente de máquinas, implementos e fertilizantes químicos, tendo como suporte a pesquisa tecnológica gerada nas escolas e centros especializados mantidos pelo Estado (Alem, 1996, p. 77). Formou-se assim um complexo siste- 
ma institucional de fomento econômico e tecnológico para a agricultura, sob a égide do projeto de desenvolvimento e segurança dos governos militares. Constituiu-se a modernidade peculiar do campo brasileiro - uma modernização sem reforma agrária. Foram deixados de fora os "produtores resistentes às mudanças", aqueles que não foram capazes de transformar seus latifúndios em empreendimentos capitalistas.

A modernização teve caráter parcial e foi socialmente excludente, produzindo desdobramentos na sociedade: concentração da propriedade da terra, intensificação das migrações campo-cidade com aumento desenfreado da população urbana, deterioração das condições de vida dos trabalhadores sem-terra e aumento das tensões e conflitos no campo entre o Movimento dos Trabalhadores Sem-Terra (MST) e os proprietários.

"A modernização rural brasileira foi seletiva, parcimoniosa e exuberante" (Alem, 1996, p. 82). Seus agentes sociais suplantaram as agências do Estado com seus intermediários pioneiros, os técnicos da extensão rural.

As instâncias de consagração da nova ruralidade são as exposições e festas ruralistas, ainda pouco estudadas pelas ciências sociais. São essas festas o espaço social onde se processa a invenção de uma nova tradição: o mundo cultural caipira/ country, fruto da reelaboração de símbolos escolhidos da ruralidade.

As exposições oferecem a oportunidade de ritualizar as posições de classe e exibir autoridade política tanto de grupos privados quanto de estatais. São, ao mesmo tempo, eventos das culturas populares em que se celebram certas tradições folclóricas e religiosas. Ou seja, elas desempenham papel similar ao das exposições universais que, desde meados do século XIX, construírame difundiram a cultura urbana industrial.

As exposições e feiras em dois estados pesquisados pelo autor (São Paulo e Minas Gerais) são produções em que acontece "uma associação íntima entre entidades de classe de proprietários do campo, especialmente os sindicatos patronais, o Estado e empresas diversas, entre os quais opera um corpo inovado de intermediários culturais"(Alem, 1996, p. 113).

Grandes empresas disputam os espaços mais visíveis e privilegiados nas feiras. Empresas menores ficam com espaços laterais. Pipoqueiros, churrasqueiros, vendedores de maçãs do amor, de amendoim, de bebidas, de artesanato (os trabalhadores informais) ficam em torno do evento permitindo compor um cenário chamado de "mercado persa" que acompanha as exposições em seu calendário por todo o Brasil.

O autor vai dar destaque aos chamados intermediários culturais: produtores das exposições, profissionais de relações públicas, publicitários, jornalistas, artistas, avaliadores e juízes de animais, leiloeiros, locutores de rodeios, além dos profissionais especializados: tropeiros e peões. Acompanhando o processo, o autor vai mostrando o passo-a-passo da organização da festa. Depois de confirmados os produtores rurais expositores, os apoios do poder público, são chamadas as empresas de publicidade que planejam e executam as estratégias de venda dos eventos. São as agências de publicidade que garantem as receitas das exposições e que produzem os conteúdos simbólicos reelaborando a configuração sertaneja (Alem, 1996, p. 132).

$O$ rural se transfigura em referencial múltiplo. Ora aponta o passado, ora o presente, ora o futuro. A festa tem normalmente elementos fixos, aqueles ligados à tradição e a certas empresas cujos produtos são ligados a produtos e insumos rurais. E elementos variáveis, aqueles mais ligados aos consumidores ou a eventos do momento. Redes de emissoras de rádio e a $\mathrm{TV}$ se encarregam de anunciar sua realização. A divulgação é feita também com caminhões com alto-falante divulgando o evento - algo entre os antigos anúncios de circo na cidade e o trio elétrico.

Os apresentadores dos shows, os mestres de cerimônia, tratam de recriar a proximidade física e simbólica fazendo apelos do tipo: "Nossos velhos companheiros de luta nas lides da roça, nossos jovens batalhadores da produção rural, nossos ar-

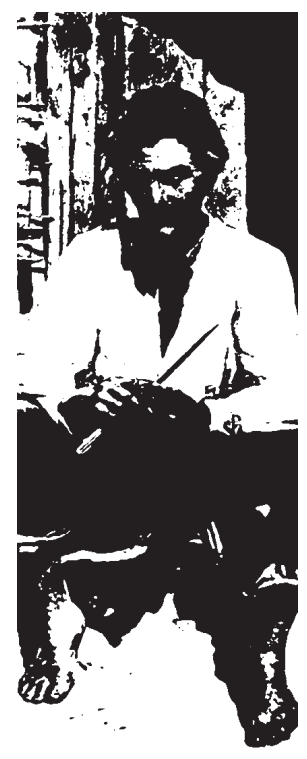


tistas do folclore. [...] Fazem a experiência social massificada parecer familiar ao impregná-la de práticas e símbolos de aparência rústica e nostálgica de um tempo que não volta mais, a não ser nas exposições" (Alem, 1996, p. 143). As exposições juntam todos, classes dominantes e dirigentes, produtores e promotores, além de peões e trabalhadores.

O rodeio se autonomizou como espetáculo nas festas rurais. "Saiu do campo da produção da cultura rústica e popular, da cultura pastoril subalterna, para o campo valorizado da produção animal, da indústria cultural e dos espetáculos de massas" (Alem, 1996, p. 156). A indústria cultural se dedica à construção dessa nova ruralidade que representa o milagre econômico e a triunfante modernização, e faz as cidades disputarem a realização de eventos que permitem inclusive aumentar seu potencial turístico.

O autor vai acompanhar a festa de Barretos mostrando as fases iniciais, quando o Clube Os Independentes a criou em 1956. Embora nenhum dos membros do clube tenha sido peão - são proprietários rurais -, eles se auto-representam como peões, como homens simples, da terra, que conviveram com o peão no manejo do gado.

O peão da boiada é certamente um dos mais importantes tipos sociais da culturapastoril no Brasil, em torno doqual foi construída uma mitologia e um imaginário presentes no folclore, no romantismo literário, no regionalismo, no modernismo de Graciliano Ramos, de Guimarães Rosa, de Mário Palmério, entre outros. As representações do caipira como peão de boiada tiveram fixação nos contos e na música, com Cornélio Pires e Capitão Furtado, que levaram suas representações para o disco e o rádio, como veremos mais detidamente adiante.

O imaginário do peão constitui um "elo entre as práticas sociais e simbólicas subalternas dos trabalhadores do campo e as que eram próprias dos sujeitos rurais dominantes [...]. O peão de boiada era produtor e condutor da riqueza das vastas regiões pecuaristas brasileiras, era o operário sertanejo que detinha o maior prestígio junto aos proprietários, ao mesmo tempo em que era um herói, um vencedor entre os sujeitos socialmente dominados" (Alem, 1996,p. 182). Tinha um saber e uma arte que podiam ser espetacularizados. Para o autor, o peão se torna central na invenção da tradição, já que ele tem um significado econômico, sem ele não haveria pecuária. E, como herói da produção, poderia ser reelaborado simbolicamente. Para o peão, tudo isso era bom, ainda que sua posição subalterna não se alterasse.

Entre as diversas modalidades de manifestação folclórica, como por exemplo as Cavalhadas (que simbolizam a luta dos cristãos contra os mouros), o rodeio foi escolhido para ser central na festa, já que suas apresentações tiveram repercussão junto ao público de todas as camadas sociais.

O sucesso da Festa do Peão de Barretos a transformou em uma imensa vitrina do folclore nacional, e por lá já se apresentaram grupos dos Centros de Tradição Gaúcha (10), de grupos do Nordeste, assim como grupos argentinos, paraguaios, bolivianos, peruanos e chilenos de folclore.

Os membros do Clube Os Independentes conseguiram deslocar a festa da produção material do agro para a produção simbólica. Retomaram as marcas do rural-popular requalificando-as: "Os caipiras de Lobato e de Mazzaropi só foram redimidos do estigma de perdedores quando curados pela ciência e quando pareciam matreiros para suplantar os inimigos da cidade [...]. Para o peão da boiada, a matreirice significa manter-se sobre os animais que pulam nos rodeios, conquistar os prêmios milionários e a fama" (Alem, 1996, p. 186). Assim se processa a síntese entre o heróico peão de boiada do Brasil central e o heróico cowboy norte-americano - é a imagem do caipira/sertanejo vencedor, "não mais retirando do campo para a máquina fabril, mas do campo para a máquina simbólica" (Alem, 1996, pp. 186-7).

A montaria dos touros, que se consolidou a partir de 1983, envolveu o reforço da face country, que se completa em 1993, quando foram estabelecidas regras para que os eventos pudessem ser uniformizados segundo o padrão do mercado internacional, 
adotado também no Canadá, Austrália, México e outros países que fazem parte do circuito mundial. Depois de nomear as diferentes provas, o autor anota que restou muito pouco do mundo caipira, das vaquejadas, touradas e outros folguedos dos vaqueiros gaúcho, nordestino ou do Pantanal.

Um formato mais regulare uniforme de competição esportiva aplicado aos rodeios busca obter uma recepção que ultrapasse as fronteiras sociais e geográficas, como se vê no futebol e nos esportes mais generalizados pelo mundo (Alem, 1996, p. 197).

Como foi possível partir da tradição, do folclore, para produzir o country brasileiro? Esta é a pergunta que o autor procura responder.

O herói central do rodeio é o peão, mas não é ele quem narra seu papel no ritual dramático da arena. “O peão é um personagem” (Alem, 1996, p. 201). Seu narrador é o locutor de rodeios, que o constrói em primeira mão, ao vivo, na arena. $\mathrm{O}$ autor transcreve várias falas do locutor ao conduzir a festa, suas emoções, seus apelos à proteção divina, seus versos que se tornam o mote central na locução do rodeio e da festa.

A elite dos locutores - Zé Prato, Barra Mansa, Tony Karrero, Asa Branca, entre outros - é formada por cerca de 20 profissionais que têm a preferência dos promotores. Eles também se envolvem na publicidade e são "donos" de outros eventos junto com empresas de publicidade, tropeiros, equipes de som e vídeo.

Os locutores apresentam o rodeio como esporte radical que tem a violência como componente fundamental e com isso o fazem, "em sua versão de ritual competitivo espetacularizado”, compartilhar do código do sertão (Alem, 1996, p. 207) (11).

"Espécie de corifeu do teatro de arena de rodeios, o locutor recita ditirambos, satiriza, ironiza, dramatiza todas as cenas e personagens do rodeio, mas, acima de tudo, valoriza a reelaboração da cultura ruralista. Enquanto narra, corre, salta, sobre as cercas, comanda o público em gestos e coros, grita, gargalha, sussurra, canta. O locutor que agrada é o que forma frases e versos com rimas de efeito, que arranca riso e aplausos da platéia" (Alem, 1996, p. 212). Esse mestre do coro exprime entusiasmo ou delírio, trabalha com a ênfase da entonação - sinaliza para o público os momentos mais graves, faz uso de erros de pronúncia reforçando o sotaque que o identifica com o mundo caipira. Eles próprios "definem a locução como o 'transe' do artista" (Alem, 1996, p. 213) (12).

A partir de eventos modelares, como os de Uberaba e Barretos, a nova ruralidade se expandiu para todo o Centro-Sul e CentroOeste, unificando as práticas ruralistas e diluindo as distinções entre o rural e o urbano, como se pode ver em festas do peão que acontecem em São Caetano, no ABC paulista (Alem, 1996, pp. 230-3).

Outro trabalho que aborda o tema do novo ruralismo é a tese de doutorado de Silvana G. de Paula (1999), que em sua pesquisa reconstituiu a genealogia do estilo country no Oeste paulista, mais precisamente no município de Presidente Prudente. Nessa região, o estilo de vida chamado country se faz presente no vestuário, no consumo e no comportamento cotidiano primeiro dos pecuaristas e depois de outras categorias sociais. A autora acompanhou as transformações acontecidas entrevistando três gerações de pecuaristas. Os mais velhos compõem a geração constituída dos desbravadores do Oeste paulista. A segunda geração consolidou os empreendimentos e seus partícipes, ainda que tenham feito cursos superiores de medicina, economia e engenharia, dedicaram-se à pecuária e foram os que estabeleceram os primeiros contatos com o country norte-americano. Observa que a região conta com a presença da empresa King Ranch, cuja sede é no Texas, e que foi a introdutora no Brasil do cavalo quarto de milha, que progressivamente substituiu a raça manga-larga na atividade pecuária. Essa segunda geração passou a ter relações com os norte-americanos visando à realização de negócios. Foram também os primeiros a visitar as feiras agropecuárias, ranchos e eventos esportivos texanos. Através de publicações norte-americanas dedicadas à criação de gado e de cavalo, foram incorporando ino-
11 A violência como componente básico do código do sertão rá foi trabalhada por diferenes autores, entre eles os que estudaram os movimentos messiânicos.

120 autor fez entrevistas com organizadores, locutores e peões de rodeios. Acompa nhou as matérias em revista especializadas como a revista Rodeio News de São José do Rio Preto, São Paulo 
vações e a mentalidade empresarial capaz de garantir a racionalidade no acompanhamento das atividades e das condições de mercado. A terceira geração já desfrutou de situação financeira consolidada e de um canal já estabelecido com os Estados Unidos por seus pais. Desse setor jovem surgiu o grupo denominado Sociedade Os Vaqueiros, que organizou o primeiro grande rodeio da cidade. Foram esses os que disseminaram a moda e o gosto country muito além dos pecuaristas e acabaram por instaurar um novo padrão estético.

Esses jovens, promotores de eventos, assim como os pecuaristas, seus pais, são habitantes da cidade. Assim, o estilo de vida country introduz o tema da ruralidade no cenário urbano. Sua composição, continua a autora, agrega tradições agrárias brasileiras, "uma peculiar interpretação da experiência country norte-americana e a aspiração de seus adeptos por instaurar a imagem e a experiência de uma ruralidade simultaneamente refinada e sintonizada com o cenário contemporâneo" (Paula, 1999, p. 17). A diferença em relação ao estilo country norte-americano é que este está associado ao labor e não à sofisticação, conjuga idéias de rusticidade e simplicidade. No Brasil o estilo está ligado à idéia de distinção, que se faria presente nos cenários de elegância e refinamento de eventos esportivos country.

Sua tese principal é que no Brasil o padrão countryé uma experiência de sociabilidade urbana inspirada no tema da ruralidade.

\section{HOMEM RURAL E SUA MÚSICA}

A questão do caipira, do homem rural, pode ser contada por vários caminhos, entre eles o da música sertaneja. Vamos acompanhar o caminho "da roça ao rodeio" apresentado por Rosa Nepomuceno (1999) em seu livro. Rica em dados e informações, a narrativa da autora partilha de algum modo das características de seu tema - "causos" do mundo da música. Mesmo assim cons- titui fonte fundamental para que se possa conhecer e acompanhar o surgimento de figuras-chaves, de compositores, de cantores, de duplas, de promotores e divulgadores do gênero ao longo do século XX.

Uma das primeiras figuras mencionados é João Pacífico, que chega a São Paulo em 1924, com 15 anos, e se torna expoente do que veio a se chamar música caipira. Sua trajetória condensa o processo daqueles caipiras que vão tentar a vida na capital e que vivenciam o processo de transformação da cidade e da música. Eles deixam a roça e vão para a cidade trabalhar nas fábricas. Trazem no saco a viola e sonham viver da música. Lutam contra a nostal gia da roça trazida pelo povo que, saído do interior, jamais se adapta completamente à vida da cidade grande.

Foram esses migrantes que, com sua viola de cinco pares de cordas duplas de arame, levaram para as cidades os cateretês, os cururus, as modas de viola, as toadas, os lundus e as congadas apreendidos em casa com seus pais, avós e bisavós. Junto com as modas de viola também difundiram crenças e lendas sobre o violeiro. "Para ser insuperável, o violeiro tem que fazer mais coisas do que simplesmente estudar e treinar. Deve recorrer aos santos, ou ao capeta, se preferir" (Paula, 1999, p. 77).

Os versos da música caipira contam as aventuras da gente que tocava gado - os tropeiros -, que fazia a ligação entre povoados isolados. Os cantadores são figuraschaves divertindo os membros da comitiva, chorando saudades, narrando "causos".

O itinerário das comitivas aponta a trilha de cidades onde a música caipira se desenvolveu. Sorocaba foi a cidade que abrigou a maior feira de muares, iniciada em 1733. Em torno desse evento, que existiu por 164 anos, foram criados outros serviços para receber os visitantes. Podemos mesmo dizer que essa feira pode ser considerada uma precursora dos atuais rodeios.

No rastro do café também itineraram lavradores, tropeiros, boiadeiros, violeiros, aventureiros, benzedores, artesãos, biscateiros entre outros. "Onde tinha café, tinha dinheiro, emprego e [...] a mais vibrante 


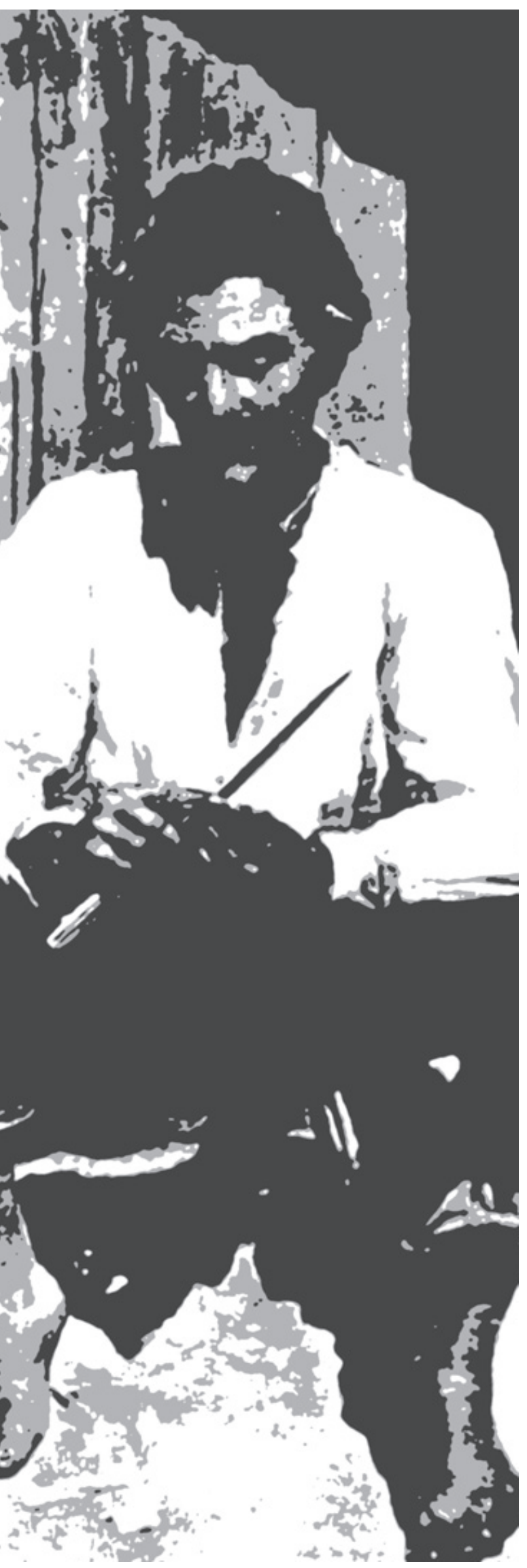

moda de viola. Nesse triângulo BotucatuPiracicaba-Sorocaba [...] vicejou o principal centro irradiador de música caipira" (Paula, 1999, p. 92). Nomes como Tonico e Tinoco, Raul Torres (filho de imigrantes espanhóis), Carreirinho, Angelino de Oliveira, são apresentados no livro. A autora informa que foi Raul Torres o responsável pelo lançamento em 1935 do disco de João Rubinato, o Adoniran Barbosa, ítalo-caipira de Valinhos. Em 1955 ele estourava com "Saudosa Maloca" e "O Samba do Arnesto", sambas com linguajar caipira e sotaque do italiano do Bexiga (Paula, 1999, p. 148).

"Ideal do Caboclo", de 1912, de Cornélio Pires, apresenta as aspirações singelas do caipira, aquelas que Lobato vai condenar em 1914. Cornélio Pires foi o folclorista fundamental na divulgação da cultura caipira do século XX. Produziu 25 livros, entre eles Musa Caipira (1910), Quem Conta um Conto (1919), Conversas ao Pé do Fogo (1921). Fez palestras, representou roceiros em monólogos criados por ele, montou caravanas de violeiros, cantadores e humoristas, apresentando-se em palcos e picadeiros. É mesmo chamado pela autora de "pai da cultura caipira".

Foi Cornélio Pires quem, em 1929, prensou o primeiro disco de música e humor caipira, percebendo que o fluxo interiorcapital continuava e até se intensificava. Levou para São Paulocantadores e violeiros da região de Piracicaba, interessado que estava em gravar a autêntica música caipira. Os discos que produziu apresentavam anedotas, desafios, declamações, cateretês, modas de viola, e foram vendidos pelo interior com enorme sucesso. Isso fez a produtora de discos Columbia reconhecer o espaço existente para esse tipo de tema e prensar outros 43 discos até o início de 1931. Foi também ele quem descobriu várias outras figuras, como Batista Júnior (pai de Linda e Dircinha) e Nhá Zefa (Maria Di Léo), preferida de Cornélio, nascida na capital e filha de italianos.

Autores teatrais, cantores e compositores, tanto populares quanto eruditos, registravam a música e a poesia dos caipiras e dos 
sertanejos. Havia uma fronteira difusa, principalmente sob o olhar da cidade grande. Tanto o caipira quanto o sertanejo estavam fugindo da pobreza e desembarcavam em São Paulo e no Rio de Janeiro com esperança de mudar de vida. Eles traziam consigo uma força muito grande para enfrentar o trabalho duro e "sobreviver ao desterro".

Acaba havendo então a fusão a partir de pontos comuns entre o sertão nordestino e a roça caipira. O maranhense Catulo da Paixão Cearense foi dos primeiros a fazer a viagem do Norte para o Sul. Ele e seu parceiro, João Pernambuco, compõem "Luar do Sertão", que se tornou uma espécie de hino sertanejo. Sob sua influência Pixinguinha cria o grupo Caxangá, que se apresentava vestindo chapéu de palha. Jararaca e Ratinho, em seu grupo chamado Turunas Pernambucanos, também usavam chapéu de cangaceiro. A autora vai apresentando cantores e grupos que fizeram a junção entre a música nordestina e a caipira. Essa era, muitas vezes, apresentada por artistas urbanos e famosos. A maioria dos cantores consagrados incluía em seus repertórios músicas sobre temas rurais. É ainda nos anos 1930 que Villa-Lobos compõe o "Trenzinho Caipira" e que Ari Barroso (mineiro) e Lamartine Babo (carioca) compõem “No Rancho Fundo”. Este último compõe também a famosa toada "Serra da Boa Esperança”.

Jararaca (alagoano) e Ratinho (paraibano), segundo a autora, sintetizam a forma de apresentação do roceiro, que podia ser mineiro, nordestino, gaúcho, paulista. Seu figurino caricato era formado pela camisa xadrez, paletó menor que o manequim, lenço e chapéu de abas curtas. Cantavam emboladas e faziam piadas com as aventuras e desventuras do matuto na cidade (13). Essa dupla nordestina que se caipirizou faz parte do grupo de artistas que criou em 1931 a Casa de Caboclo (nome de uma peça de Freire Júnior de 1928) e que forjou um pedaço do sertão brasileiro na Praça Tiradentes, no Rio de Janeiro. Alvarenga (mineiro)e Ranchinho (paulista) compõem outra dupla famosa que atuou como caipira no filme Fazendo Fitas, de 1935, de Ariovaldo Pires, o Capitão Furtado, figura também importante no campo de música caipira e sobrinho de Cornélio Pires.

O rádio foi, fora de dúvida, o meio fundamental para a difusão do gênero. Trazia caipiras de primeira linha para se apresentarem, tinha horários dedicados ao público que migrava do interior. Em seus esquetes de humor, de casos, de música, apresentados ao vivo, o caipira obviamente levava vantagem sobre o homem da cidade. Os humoristas exploravam os traços cômicos de sua personalidade-como a mania de mentir para pregar peças no habitante da cidade. No período áureo do rádio e do cinema caipira de Mazzaropi, ainda se mantém uma visão ambígua sobre o caipira, sobre o Jeca: ele é bobo e esperto ao mesmo tempo. Sua fala mole aparentemente inocente esconde uma malandragem particular.

Vejamos como Rosa Nepomuceno conta o surgimento de outros tipos famosos:

"No Arraial do Capitão Furtado, em 1943, apareceu um trio simplezinho, malvestido, formado pelos irmãos Perez e mais um primo que tocava sanfona. Lá das plantações de café e algodão das fazendas de Botucatu, os filhos de um imigrante espanhol, chegavam dispostos a sair da situação de extrema pobreza em que viviam [...]. Venceram o concurso para substituir os principais violeiros do programa [de rádio] e arrumaram o emprego. Capitão comentou que aquele nome espanhol não combinava com uma dupla tão original e brasileira. Sugeriu o nome Tonico e Tinoco, e assim passaram a ser apresentados. Dois anos depois gravaram o primeiro disco, 'Em vez de me agradecê' [...]. Teriam, a partir daí, a carreira mais brilhante e estável das duplas caipiras..." (Nepomuceno, 1999, p. 135).

Em Botucatu apareceu, em 1943, um humorista mambembando em galpões alugados: era o paulista Mazzaropi. Apresentando-se em circos, fazia sucesso cantando “Tristezas do Jeca”, de outro músico, Roque Ricciardi, que adotou o nome artístico de Paraguassu. 
Filho de pai italiano e mãe portuguesa, nascido em São Paulo, Mazzaropi passou sua infância à porta dos circos. Aos 20 anos, em 1932, já era conhecido nos picadeiros e nos auditórios de rádio onde se apresentava. Criou um tipo, vestido com calça pesca-siri, chapéu de palha desfiado e botina desengonçada, e conseguiu ser considerado o melhor intérprete do Jeca Tatu. Até o final da década de 1940 já tinha produzido, dirigido e estrelado dez filmes, ficando tão popular quanto rico e lotando salas de todo o país (Nepomuceno, 1999, p. 155).

Os momentos gloriosos da música e do humor caipira foram, segundo Rosa Nepomuceno, os anos 1940 e 1950, já nos anos 1960 a música sertaneja perdeu espaço. Nas cidades ela teve que enfrentar a bossa nova e o rock. Seu público era aquele mais ligado a festas tradicionais que aconteciam no interior e na periferia das cidades. Ficou sendo a música do pobre, do interiorano e do suburbano, e teve seu lugar definido era de segunda classe, do quintal, da cozinha. Os nomes do período áureo, como Tonico e Tinoco e Inezita Barroso, ficaram relegados a programas do tipo "hora da saudade".

Acompanhando a trajetória da música de inspiração rural, Rosa Nepomuceno vai ressaltar os primeiros passos do ressurgimento da música caipira. Chitãozinho e Xororó surgem em 1970; Milionário e Zé Rico estouraram em 1975; Sérgio Reis, Rolando Boldrin, Almir Sater são figuras da nova safra. Mas, a essa altura, o mundo sertanejo estava dividido. De um lado, os quase marginais, apegados às tradições. De outro, os que procuravam a integração com as novidades do mercado e que vendiam mais.

Chitãozinho e Xororó, apresentando as "baladas rancheiras com roupagem pop cantadas em terças", "criaram um abismo intransponível entre os dois mundos - o da música tradicional (14) e o da sertaneja moderna" (Nepomuceno, 1999, p. 197).

Os artistas do boom sertanejo da década de 1980 cantavam para um Brasil que voltava a ter no campo grande força econômica, quase seis décadas depois de ter experimentado o período mais rico da cultura cafeeira. A mão-de-obra continuava a ser despachada para as cidades, mas isso não interferia no crescimento do chamado agrobusiness, importador de máquinas e modernizador dos processos produtivos. Café, cana-de-açúcar e gado garantiam vendas no mercado externo, dólares e mudanças de costumes em regiões do interior. Enquanto isso, as metrópoles se empobreciam, inchadas pela população pobre expulsa do campo, gerando desemprego, violência e expondo a precariedade da sua infraestrutura. Maringá e Cascavel no Paraná, Ribeirão Preto e São José do Rio Preto em São Paulo, Uberaba e Uberlândia em Minas, Rondonópolis no Mato Grosso, estão entre as cidades do interior que modificavam o cenário e os valores rurais.

Os filhos dos ricos e da classe média passaram a preferir se fixar no interior. Não era mais necessário ir para a capital para ter acesso a informação e a bens de consumo, a boas universidades e a oportunidades profissionais. Os interioranos, em vez de seguirem a reboque dos padrões da cidade, agora foram buscar no country norte-americano os novos modelos de vestuário, de lazer e de música. Eles se permitiam casar a alma rural com o progresso e com a riqueza, e não mais a alma ingênua com a pobreza (Nepomuceno, 1999, p. 201).

Chitãozinho e Xororó traduzem esse interior rico, farto, ligado on line ao primeiro mundo: eles "foram os primeiros a dar maior dimensão à ligação sertanejocountry, inaugurada no final dos anos 1940 por Bob Nelson, [e] também foram os últimos, na geração dos astros populares, a ostentar a sua herança rural. Ela está nos seus primeiros discos, onde cantaram as modas do Capitão Furtado, e mais tarde, em 'Clássicos Sertanejos', de 1996" (Nepomuceno, 1999, p. 204).

“'O repertório de reggaes, baladas românticas, rocks e música country já estava incorporado ao novo gênero sertanejo e deixava também de ser cantado necessariamente em duas vozes (vide Leonardo e Daniel, que continuaram a fazer sucesso após a morte de seus parceiros, Leandro e João Paulo).
14 A empresa Kuarup discos tem apresentado o que há de methor no clássico sertanejo. No CD No Sertão; Violas e Cordas, Roberto Corrêa é apresentando como homem do sertão de Minas, violeiro que junta o conhecimento erudito e a pesquisa da tradição da vioa. Nesse CD estão "Luar do Sertão", de João Pernambuco e Catulo da Paixão Cearense "Asa Branca" de Luiz Gon zaga e Humberto Teixeira "Viola Enluarada", de Marcos e Paulo Sérgio Valle, entre outros clássicos do gênero. Ve site www. kuarup.com.br e e mail kuarup@kuarup.com.br 


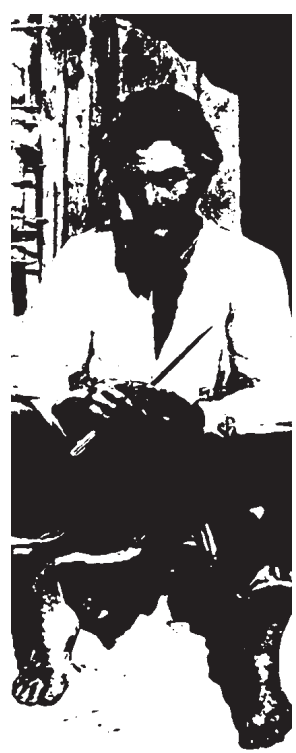

No caso desses dois cantores, o tratamento mercadológico procurou diluir ao máximo a marca interiorana dos moços, reforçando a imagem de galãs simpáticos. Os dois adotam a postura de cantores românticos, dispensando o rótulo de sertanejos" (Nepomuceno, pp. 213-4).

Para os críticos a música caipira perdeu todo o vínculo com o campo, abandonou as origens. O único ponto de identificação com o universo rural são os temas do boi e do peão, que são mantidos por causa dos rodeios que atraem grande público. Para a autora, entretanto, ainda existem traços da música caipira de raiz. O Clube Os Independentes, responsável pela festa de Barretos, por exemplo, promove o festival Violeira, onde surgem novos músicos da autêntica música caipira.

Esse processo da roça ao rodeio foi coroado pelas novelas quando a música caipira deixou de ser ouvida e tocada no quintal e chegou à sala. A viola de Almir Sater, as modas de Sérgio Reis, o ambiente rural e o dialeto caipira marcaram Pantanal, em 1990, e Ana Raio e Zé Trovão, em 1991 na Manchete e, em 1996, na Globo, O Rei do Gado. Assim, um fenômeno aparentemente ligado ao local, ao tradicional, ao regional, ao folclore, torna-se bem de consumo moderno, desejável por amplos segmentos da população e inserido na globalização.

Como já escrevemos páginas atrás: a forma de recontar o processo de reajuste da economia brasileira aos avanços do capitalismo mundial é variável, ora é visto como avanço, ora como decadência, ora valoriza-se o lado da modernização, ora da ruína.
Quanto mais globalizada, mais localista, e é nessa simbiose que ganham sentido os novos caipiras-countries.

Procuramos acompanhar como a historiografia paulista, os intelectuais no princípio do século e, mais tarde, a produção originária do espaço da universidade tratou do homem do interior e discutiu seu papel no processo de modernização então em curso. A incorporação das camadas populares européias, os camponeses imigrantes, ao mundo rural paulista também confere um sentido especial a esse processo. Abordamos o tema explorando algumas obras (de Antonio Candido, Maria Isaura Pereira de Queiroz e João Baptista Borges Pereira) que marcaram essa produção acadêmica chamada de sociologia esquecida. A modernização do campo brasileiro - sem reforma agrária, entendida como distribuição de terras - criou uma nova ruralidade que se faz perceptível em suas festas e comemorações. A associação entre modernização do campo e indústria cultural se faz presente na Festa do Peão de Barretos tomada como exemplar da constituição do peão-cowboy. Fizemos a leitura desse trajeto acompanhando a música popular e demos destaque também a figuras de sucesso da cultura popular que passaram do mundo imigrante para o caipira, como por exemplo Tonico e Tinoco, Mazzaropi, Adoniran Barbosa, entre outros. E, por fim, procuramos sinalizar de que modo o agrobusiness e o circuito de rodeio constituíram o espaço social para que o caipira, ou o atrasado de ontem, se tornasse o globalizado de hoje.

\section{BIBLIOGRAFIA}

ALEM, João Marcos. Caipira e Country: a Nova Ruralidade Brasileira. Tese de doutorado. Departamento de Sociologia, USP, 1996.

ANTUNIASSI, Maria Helena Rocha. "Mundo Rural e Agricultura no Brasil", in Ethel V. Kosminsky (org.). Agruras e

Prazeres de uma Pesquisadora: Ensaios sobre a Sociologia de Maria Isaura Pereira de Queiroz. Marília/São Paulo, Unesp/Fapesp, 1999, pp. 125-36. 
BerRIEL, Carlos Eduardo Ornelas. Tietê, Tejo, Sena. A Obra de Paulo Prado. Campinas, Papirus, 2000.

CHIAPPINI, Lígia. "Do Beco ao Belo: Dez Teses sobre o Regionalismo na Literatura", in Estudos Históricos, vol. 8, n.

15, Rio de Janeiro, 1995, pp. 153-9.

COLI, Jorge. "A Violência e o Caipira", in Estudos Históricos, n. 30, Rio de Janeiro, 2002, pp. 23-31.

D’AQUINO, Teresinha. "0 Olhar de Maria Isaura sobre o Rural: Tradição e Mudança", in Ethel V. Kosminsky (org.).

Agruras e Prazeres de uma Pesquisadora: Ensaios sobre a Sociologia de Maria Isaura Pereira de Queiroz. Maŕlia/ São Paulo, Unesp/Fapesp, 1999, pp. 161-71.

DIAS, Maria Odila Leite da Silva. "De Monções a Caminhos e Fronteiras", in Revista do Brasil, ano 3, n. 6, 1987, pp. 63-7 (número especial dedicado a Sergio Buarque de Holanda).

DURHAM, Eunice R. A Caminho da Cidade; a Vida Rural e a Migração para São Paulo. São Paulo, Perspectiva, 1984. FERREIRA, Antonio Celso. "Vida (e Morte?) da Epopéia Paulista", in Antonio Celso Ferreira; Tania Regina de Luca; Zilda Grícoli lokoi. Encontros com a História: Percursos Históricos e Historiográficos de São Paulo. São Paulo, Unesp, Fapesp, Anpuh/SP, 1999, pp. 91-106.

FRANC0, Maria Sylvia de Carvalho. Homens Livres na Ordem Escravocrata. 3a ed. São Paulo, Kairós, 1974 (1a ed., Instituto de Estudos Brasileiros/USP, 1969).

GIULIANI, Gian Mario. "Neo-ruralismo: o Novo Estilo dos Velhos Modelos", in Revista Brasileira de Ciências Sociais, n. 14, s.d.

JACKSON, Luiz Carlos. "A Tradiç̃o Esquecida; Estudos sobre a Sociologia de Antonio Candido", in Revista Brasileira de

Ciências Sociais, vol. 16, n. 47, outubro de 2001, pp. 127-40.

A Sociologia Esquecida; os Parceiros do Rio Bonito e a Sociologia de Antonio Candido. Belo Horizonte/

São Paulo, UFMG/Fapesp, 2002.

LAJOLO, Marisa. Monteiro Lobato; um Brasileiro sob Medida. São Paulo, Moderna, 2000.

LIMA, Nísia Trindade. Um Sertão Chamado Brasil. Rio de Janeiro, Revan/luperi, 1999.

LIMONGI, Fernando. "A Escola Livre de Sociologia e Política em São Paulo", in Sérgio Miceli (org.). História das

Ciências Sociais no Brasil. Volume 1. São Paulo, Vértice/Idesp, 1989, pp. 217-33.

MARTINS, José de Souza. A Imigração e a Crise do Brasil Agrário. São Paulo, Perspectiva, 1973.

NePOMUCENO, Rosa. Música Caipira: da Roça ao Rodeio. São Paulo, Editora 34, 1999.

OLIVEIRA, Lucia Lippi. Os Italianos no Melting Pot Paulista, 2002 (mimeo.).

PAULA, Silvana G. de. "0 Country no Brasil Contemporâneo", in História, Ciências, Saúde - Manguinhos. volume V Suplemento, julho de 1990, pp. 273-86.

. Campo na Cidade. Esportes Country e Ruralidade Estetizada. Tese de doutorado. Iperi/Ucam, 1999.

PEREIRA, João Baptista Borges. Italianos no Mundo Rural Paulista. São Paulo, Edusp, 2001.

PROENÇ, Manuel Cavalcanti. "Caminhos e Fronteiras", in Revista do Brasil, n. 6, Rio de Janeiro, jul./1987, pp. 68-

75 (número especial dedicado a Sergio Buarque de Holanda).

QUEIROZ, Maria Isaura Pereira de. Bairros Rurais Paulistas, Dinâmica das Relações Bairro Rural-Cidade. São Paulo,

Livraria Duas Cidades, 1973.

RODRIGUES, Sônia Maria Braucks Calazans. Jararaca e Ratinho, a Famosa Dupla Caipira. Rio de Janeiro, Funarte, 1983.

SANTOS, José Vicente Tavares dos. "Crítica da Sociologia Rural e a Construção de uma outra Sociologia dos Processos

Sociais Agrários", in Ciências Sociais Hoje. Anpocs, 1991.

WANDERLEY, Maria de Nazareth B. "Uma Categoria Rural Esquecida: os Desafios Permanentes da Sociologia Rural

Brasileira", in Ethel V. Kosminsky (org.) Agruras e Prazeres de uma Pesquisadora: Ensaios sobre a Sociologia de

Maria Isaura Pereira de Queiroz. Marília/São Paulo, Unesp/Fapesp, 1999, pp. 137-60.

WERNER, Robert. A Conquista do Oeste; a Fronteira na Obra de Sergio Buarque de Holanda. Belo Horizonte, UFMG, 2000.

YASUDA, Enid. "0 Caipira e os Outros", in Alfredo Bosi (org.). Cultura Brasileirra: Temas e Situaç̃oes. São Paulo, Ática,

1992, pp. 103-13. 